\title{
Experimental Study on Fatigue Performance of Negative Bending Moment of Steel-Concrete Continuous Composite Box Girder
}

\author{
Pu Gao, ${ }^{1}$ Kuan $\mathrm{Li}^{2}$ and Yuanxun Zheng $\mathbb{D}^{2}$ \\ ${ }^{1}$ Technology Center, China Construction Sixth Engineering Division Corp. Ltd., Tianjin 300451, China \\ ${ }^{2}$ School of Water Conservancy Science and Engineering, Zhengzhou University, Zhengzhou, Henan 450001, China \\ Correspondence should be addressed to Yuanxun Zheng; yxzheng@zzu.edu.cn
}

Received 3 May 2020; Revised 30 May 2020; Accepted 15 June 2020; Published 9 July 2020

Academic Editor: Grzegorz Golewski

Copyright $\odot 2020 \mathrm{Pu}$ Gao et al. This is an open access article distributed under the Creative Commons Attribution License, which permits unrestricted use, distribution, and reproduction in any medium, provided the original work is properly cited.

The experimental work presents results on the fatigue performance of composite beams in the negative moment region and the changes of stiffness and deformation of composite beams under repeated loads; fatigue tests were carried out on two double-layer composite beams. The fatigue performance of composite beams with different reinforcement ratios under complete shear connection and the variation of deflection, strain of the reinforcement, strain of steel beam, and crack growth under fatigue load were obtained. The results showed that the fatigue resistance performance of concrete slab with low reinforcement ratio was much lower than that of concrete slab with high reinforcement ratio whereas, under the fatigue load, the stress of the welding nail in the negative moment region was small and the slip was almost negligible. The degradation of stiffness and the development of cracks were mainly due to the degradation of bond-slip between the concrete and reinforcement. The fatigue failure mode was the fracture of the upper reinforcement in negative moment region. The results obtained in this study are helpful in the design of composite beam.

\section{Introduction}

Steel-concrete composite beam is a kind of flexural structure which connects steel beam and concrete slab as a whole. It can make full use of the material properties of steel and concrete and has significant advantages as small structural height, light weight, high bearing capacity, large stiffness, and good comprehensive benefits [1-3]. However, in the process of use, the negative bending moment exists at the fulcrum in the continuous composite beam bridge, when concrete slab is under tension, steel beam bottom plate and web are under compression, the performance of the two materials is not effectively achieved, and concrete slab in most cases is unfavorable under tensile condition [4-6]. Concrete with low tensile strength will crack when the load is very small. After cracking, the section stiffness of negative moment region decreases, and the concrete slab and steel beam have a relative slip, which leads to the redistribution of the internal force of the structure and affects the mechanical performance of the whole composite beam. The mechanical properties of the negative moment region of the concrete slab after cracking are complicated and must be studied through experiments.

The control area of the continuous composite beam is the negative moment region. The crack of concrete in negative bending area, the stress of reinforcement in concrete slab, and the buckling and fatigue of steel beam are the research emphases of continuous composite beam. In recent years, researchers have done considerable experiments on the static properties of steel-concrete composite beams. Barnard and Johnson [7] and Mallick and Chattopadhyay [8] showed that as long as secondary failure could be avoided, it was feasible to design most continuous composite beams according to the simplified plastic method. Hamada and Longworth [9] conducted tests on three continuous composite beams with two equal spans; their study showed that the failure mode was based on the crushing of concrete in the positive moment region or the local buckling of steel beam flange in the negative moment region, the ultimate load of continuous composite beams could be accurately calculated, 
and the amount of longitudinal reinforcement was the main factor influencing the failure mode in the negative moment region. Johnson et al. $[10,11]$ conducted tests on three-span continuous composite beams; their results indicated that the design of continuous composite beams is often controlled by the yield and cracking of materials under the service load. Johnson and May $[12,13]$ studied the vertical shear capacity of continuous composite beams through experiments, respectively, including the shear distribution of concrete slabs and steel beams. The results showed that the concrete slab can withstand about $20 \%$ of the total shear capacity in ordinary continuous composite beams and can even withstand $50 \%$ of the total shear capacity in slim sections. Johnson [14] conducted experimental studies on the shear strength and flexural stiffness of continuous composite beams, believing that the shear stiffness of sections is proportional to the number of shear joints, and shear connectivity is an important parameter in the design of continuous composite beams. Grant et al. [15] made a theoretical and experimental study on the influence of shear connection on the mechanical properties of continuous composite beams and concluded that the reduction of shear connection could greatly affect the bearing capacity of beams. Gautam [16] considered that shear nails, as a component of steel-concrete composite structure, play an important role in the performance of composite structure. Therefore, the influence of group columns on simply supported continuous box girder was studied, and the experimental results displayed that the higher the shear connectivity, the smaller the maximum slip value.

In recent years, the fatigue performances of steel-concrete composite beams have also been studied experimentally. Liao [17] obtained that the fatigue life of the welding nails was mainly controlled by the stress amplitude and not affected by the maximum stress. The strength of concrete has little influence on the fatigue life of welding nails. Fatigue load test of composite beams was carried out by Yen et al. [18]; and the test results revealed that it was recommended to use complete shear connection to avoid excessive deformation of composite beams under fatigue load. The type of reinforcement had significant effect on the fatigue performance of the beam. The composite beams with fine steel hinge lines displayed better fatigue resistance than the composite beams with reinforcement. Considering the particularity of composite beams connected by partial shear force, the corresponding experimental studies were conducted by Geattesco et al. [19]; and the test results showed that the European code 3 tended to be conservative when evaluating the fatigue life of internal bolts of composite beams, and the fatigue performance of internal bolts of beams was better than that of internal bolts of specimens under the same conditions. Youn et al. [20] conducted static loading and fatigue loading tests on the 1:5 composite bridge model, and the test results showed that when the load was applied to the middle of the bridge panel, the static strength and fatigue strength of the bolt were higher than those when the load was applied near the support. Johnson [21] summarized many representative research results and the latest provisions of several internationally popular codes, adopted the European code model, and suggested that the fatigue life of composite beams should be calculated as follows: $\log \mathrm{NK}+5.5 \log \Delta \tau=16.4$.

In the review of both domestic and foreign literature, most studies mainly focused on the stiffness degradation caused by the sliding of welding nails under repeated loads and the fatigue failure of welding nails [22, 23] but there were few studies on the crack development of concrete bridge slab after cracking and the failure pattern of bridge slab caused by reinforcement fracture. The mechanism of stiffness degradation and fatigue failure of composite beams connected by complete shear force under repeated loads was rarely studied. In this paper, through the design of two reverse-loading simply supported composite beams, the mechanical behavior of the negative moment region of double-layer composite beams with different reinforcement ratios under monotone and repeated loads was studied. The crack development of concrete slab in negative moment region, the change of sectional stress of composite beam, the change of midspan deflection of composite beam, and the fatigue failure pattern were observed, and the results provided a reference for the design of composite beam.

\section{Experimental Model Design}

2.1. Experimental Beam Design. In order to make the test model truly reflect the stress characteristics of the actual composite beam bridge, this study simplified the scale of a continuous composite beam bridge and designed the test beam model in accordance with the principle that the relative height of the neutral axis remained unchanged, the structural stiffness was equivalent, and the shear connection degree was the same. The design parameters and loading mode of the test beam are shown in Table 1. The total length of the composite beam was $5.5 \mathrm{~m}$, the distance between two supports was $4.9 \mathrm{~m}$, the beam height was $0.55 \mathrm{~m}$, and the beam width was $1.4 \mathrm{~m}$. The transverse and longitudinal sections of the test beam are shown in Figures 1 and 2 .

2.2. Design of Welding Nail Connector. In order to effectively combine concrete and steel, a certain number of welding nail connectors were arranged on the floor of the steel beam to strengthen the connection between steel and concrete, as shown in Figure 3. The floor concrete was $95 \mathrm{~mm}$ thick, the top layer was covered with reinforcing mesh, the longitudinal steel bar had a diameter of $8 \mathrm{~mm}$ and a spacing of $70 \mathrm{~mm}$, and the transverse steel bar had a diameter of $6 \mathrm{~mm}$ and a spacing of $90 \mathrm{~mm}$. The concrete structure of base plate is shown in Figure 4. The welding nail connectors were arranged in a continuous manner, as shown in Figure 5.

2.3. Design of Bridge Deck. The PLG-1 and PLG-2 test beams used ordinary reinforced concrete bridge decks. In order to study the influence of different reinforcement ratio on the mechanical properties of composite beams, concrete slabs with the reinforcement ratio of $0.86 \%$ and $1.72 \%$ were used, respectively. The reinforcement structure is shown in Figure 6. 
TABLE 1: Parameters of composite beam specimens.

\begin{tabular}{|c|c|c|c|c|c|c|}
\hline $\begin{array}{l}\text { Specimen } \\
\text { no. }\end{array}$ & Section form & $\begin{array}{l}\text { Layout of upper } \\
\text { flange welding nails }\end{array}$ & $\begin{array}{c}\text { Number of upper } \\
\text { flange welding } \\
\text { nails }\end{array}$ & $\begin{array}{l}\text { Reinforcement ratio of } \\
\text { concrete slab (\%) }\end{array}$ & $\begin{array}{c}\text { Measured compressive } \\
\text { strength of concrete } \\
(\mathrm{MPa})\end{array}$ & $\begin{array}{l}\text { Loading } \\
\text { method }\end{array}$ \\
\hline PLG-1 & $\begin{array}{c}\text { Double- } \\
\text { layer } \\
\text { concrete }\end{array}$ & $\begin{array}{l}\text { Continuous } \\
\text { arrangement }\end{array}$ & 176 & 1.76 & 59.05 & $\begin{array}{c}\text { Repeated } \\
\text { loading }\end{array}$ \\
\hline PLG-2 & $\begin{array}{l}\text { Double- } \\
\text { layer } \\
\text { concrete }\end{array}$ & $\begin{array}{l}\text { Continuous } \\
\text { arrangement }\end{array}$ & 176 & 0.88 & 60.18 & $\begin{array}{l}\text { Repeated } \\
\text { loading }\end{array}$ \\
\hline
\end{tabular}

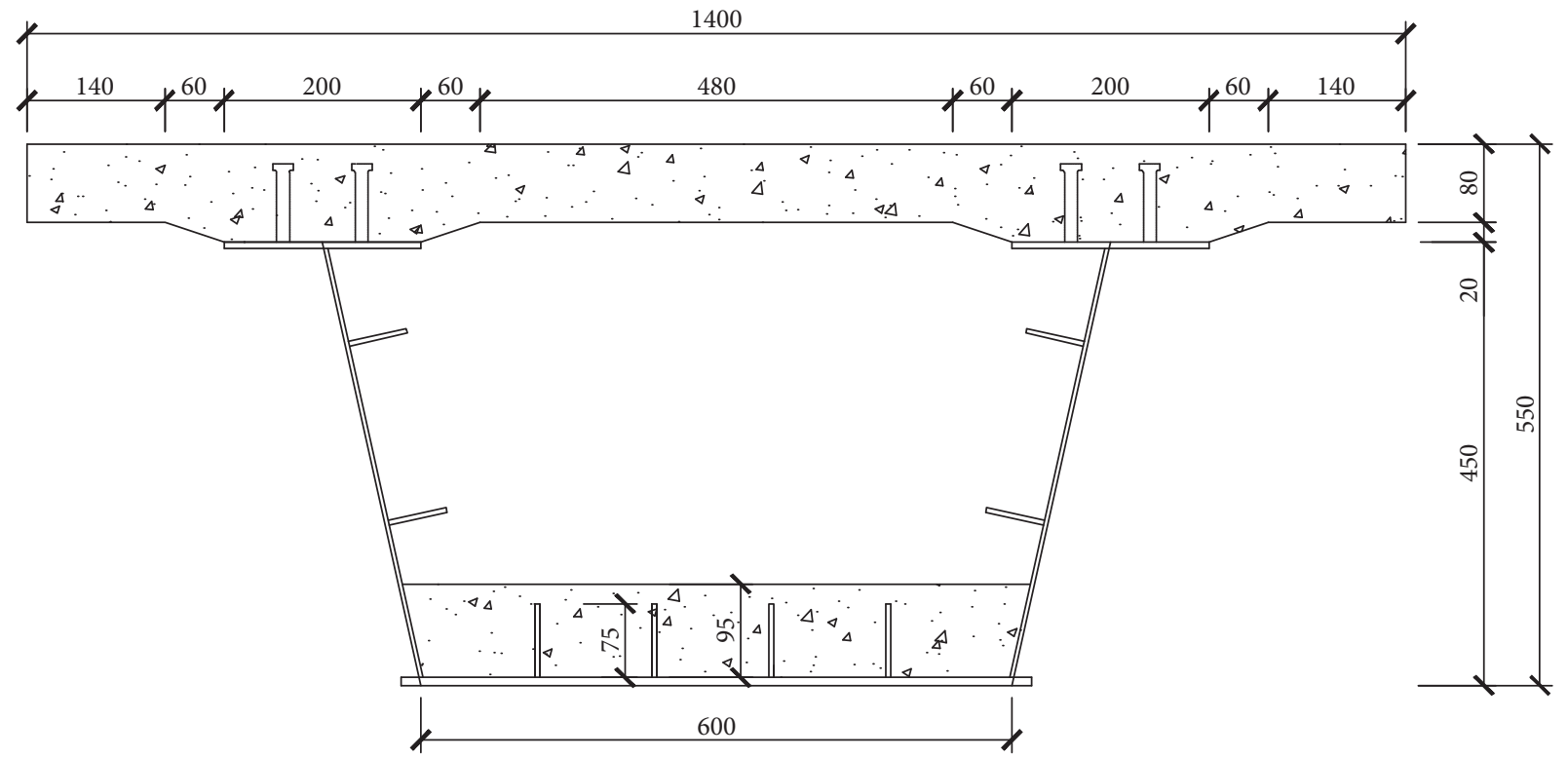

Figure 1: Cross section of test beam (unit: $\mathrm{mm}$ ).

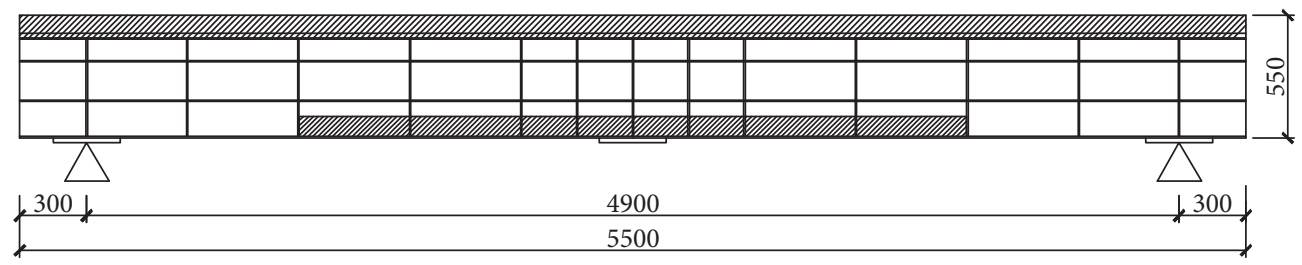

FIgURE 2: Longitudinal section of test beam (unit: $\mathrm{mm}$ ).

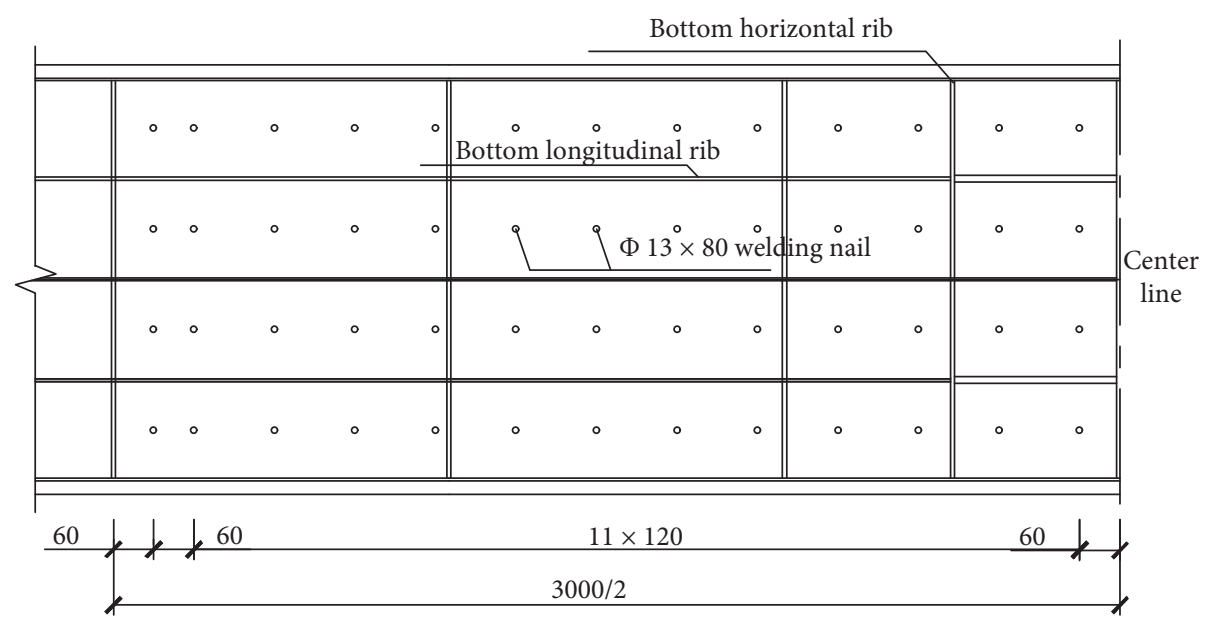

FIgURE 3: Layout of welding nails on the bottom plate (unit: $\mathrm{mm}$ ). 


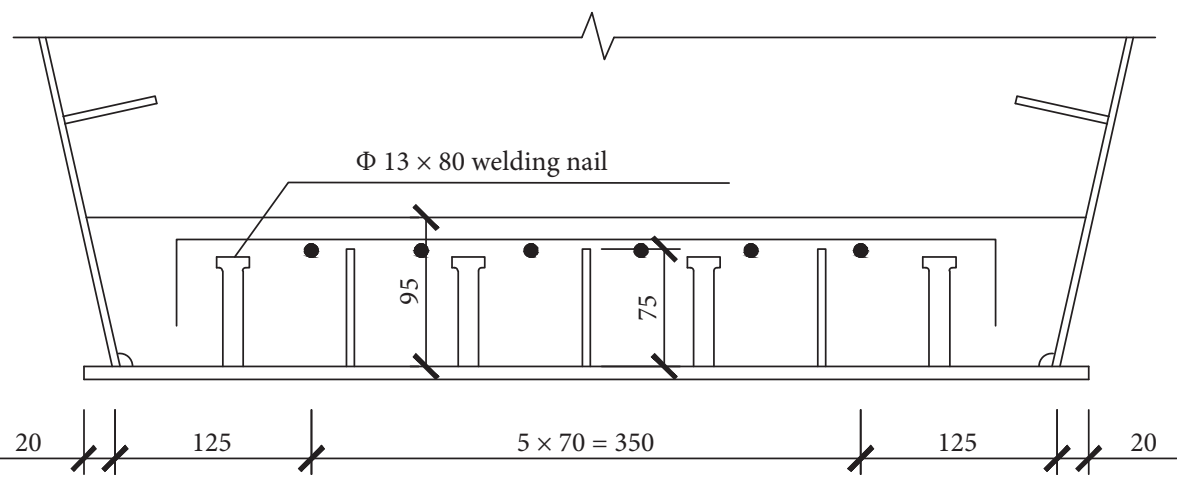

FIgURE 4: Concrete structure of base plate (unit: $\mathrm{mm}$ ).

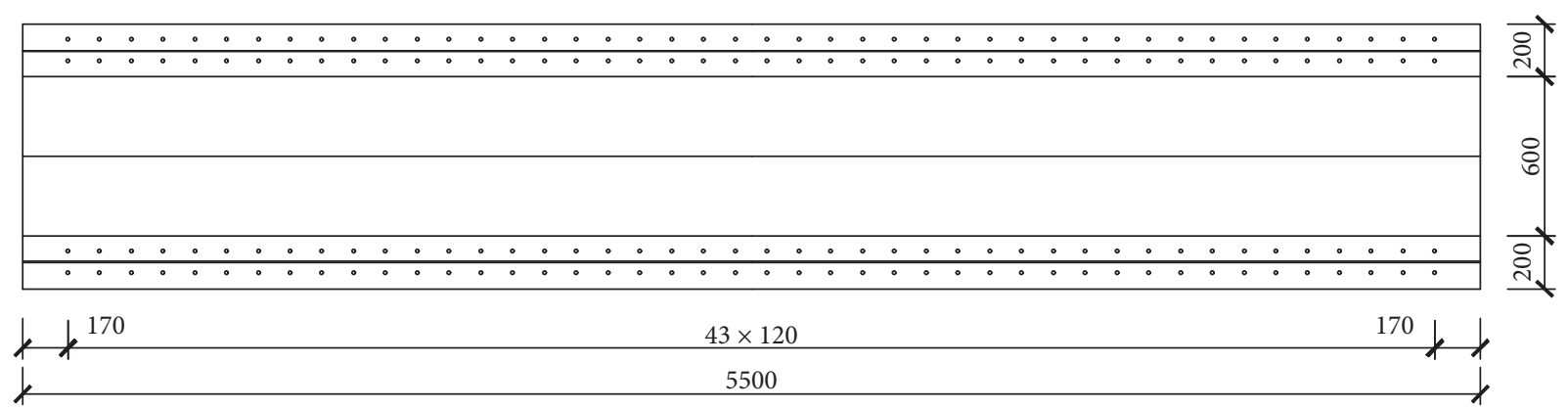

FIGURE 5: Layout of welding nails on the upper flange (unit: $\mathrm{mm}$ ).

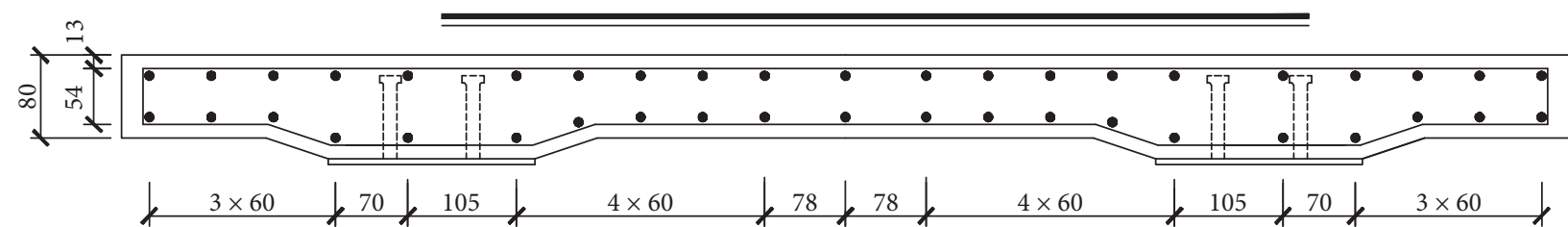

(a)

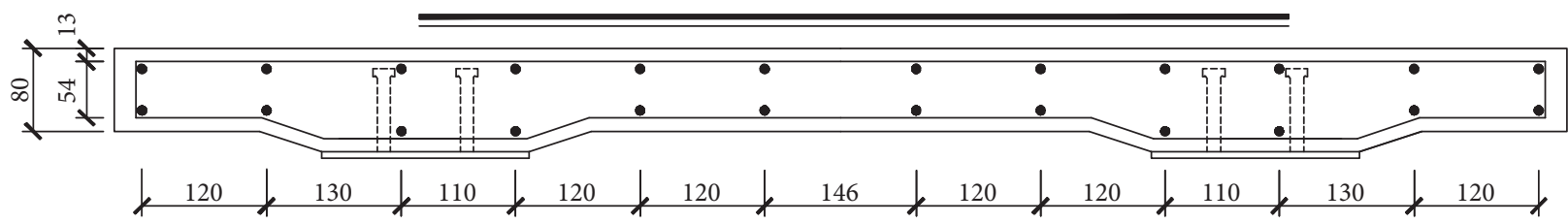

(b)

FiguRE 6: Structure of ordinary reinforcement in concrete slabs (unit: mm). (a) PLG-1: reinforcement ratio 1.72\%. (b) PLG-2: reinforcement ratio $0.86 \%$.

2.4. Basic Mechanical Properties of Concrete. The concrete was all commercial concrete, according to the test method in GB/T 50081-2002 Standard for Testing Methods of Mechanical Properties of Ordinary Concrete; the compressive strength, tensile strength, and elastic modulus of concrete cubes with ages of 7 days and 28 days were tested. The specimen size used in the compressive strength and tensile strength tests was $150 \mathrm{~mm} \times 150 \mathrm{~mm} \times 150 \mathrm{~mm}$, and the size of the specimen used in the elastic modulus test was
$150 \mathrm{~mm} \times 150 \mathrm{~mm} \times 300 \mathrm{~mm}$. The basic mechanical properties of concrete at 7 days and 28 days are shown in Table 2 .

\subsection{Experimental Scheme Design}

2.5.1. Loading System. This test was performed in the laboratory of the Institute of Structural Engineering and Disaster Prevention of Tongji University. The loading 
TABLE 2: Basic mechanical properties of concrete at 7 days and 28 days.

\begin{tabular}{|c|c|c|c|c|}
\hline Age/day & Test type & Specimen number & Measured value $(\mathrm{MPa})$ & Use value (MPa) \\
\hline \multirow{9}{*}{7} & \multirow{3}{*}{ Compressive strength } & 1 & 46.23 & \multirow{3}{*}{46.93} \\
\hline & & 2 & 49.38 & \\
\hline & & 3 & 45.19 & \\
\hline & \multirow{4}{*}{ Tensile strength } & 1 & 2.76 & \multirow{4}{*}{3.08} \\
\hline & & 2 & 3.01 & \\
\hline & & 3 & 3.47 & \\
\hline & & 1 & 32800 & \\
\hline & \multirow[t]{2}{*}{ Elastic modulus } & 2 & 38900 & \multirow[t]{2}{*}{35300} \\
\hline & & 3 & 34100 & \\
\hline \multirow{9}{*}{28} & \multirow{3}{*}{ Compressive strength } & 1 & 52.26 & \multirow{3}{*}{56.42} \\
\hline & & 2 & 56.1 & \\
\hline & & 3 & 60.89 & \\
\hline & \multirow{3}{*}{ Tensile strength } & 1 & 3.52 & \multirow{4}{*}{3.68} \\
\hline & & 2 & 3.83 & \\
\hline & & 3 & 3.7 & \\
\hline & \multirow{3}{*}{ Elastic modulus } & 1 & 36500 & \\
\hline & & 2 & 43900 & \multirow[t]{2}{*}{40500} \\
\hline & & 3 & 41100 & \\
\hline
\end{tabular}

equipment used was the PMS-500 fatigue tester. The maximum load was $1000 \mathrm{kN}$ and the maximum frequency was $10 \mathrm{~Hz}$. The loading method of simply supported composite test beam with negative moment is shown in Figure 7. Due to the test site and loading method, the test beam was hoisted in the opposite direction, with the concrete slab facing down and the bottom plate facing up. Repeated loads were placed in the middle of the beam span by the distribution beam; the loading diagram is shown in Figure 8.

2.5.2. Loading Procedure. According to the results of the Liu [24] static load test, the upper limit of the load of PLG-1 was $490 \mathrm{kN}$ and the lower limit was $225 \mathrm{kN}$. In order to prevent the cracks from appearing too wide during the entire test, the initial load limit of the fatigue test piece PLG-2 was $190 \mathrm{kN}$, and the variable load method was used gradually to increase the maximum load limit and load amplitude.

PLG-1 was loaded in two ways, static and dynamic. The static load was divided into 10 levels, with the maximum load being $490 \mathrm{kN}$ and the load of each level being $49 \mathrm{kN}$. The upper and lower limits of the dynamic load were $225 \mathrm{kN}-490 \mathrm{kN}$, with $4 \mathrm{~Hz}$ loading frequency. The specific loading process was as follows: before the dynamic load was applied, three static loads were applied to make the concrete slab crack, so as to simulate the cracked working state of the bridge deck. The dynamic load was stopped every 250,000 cycles, and a static load was applied after each stop to measure strain and deflection and observe cracks. After 2 million dynamic loads, the test beam had not been damaged, the upper limit load and the stress amplitude will be increased, and the observation will be stopped every 250,000 cycles until the final failure.

PLG-2 adopted the method of variable amplitude loading because the reinforcement ratio was small, the stress of the steel bar under the same load was also large, and the cracks appeared earlier. Therefore, the load was gradually increased by increasing the upper limit of the load and the load amplitude. The static load was divided into 10 levels,

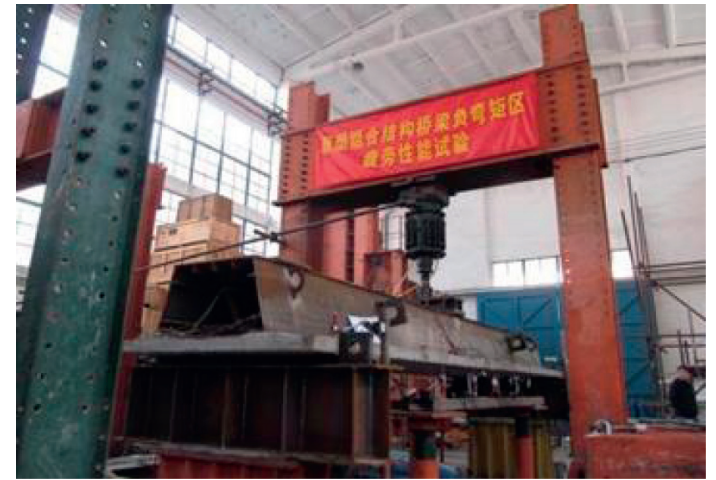

Figure 7: Test beam loading site.

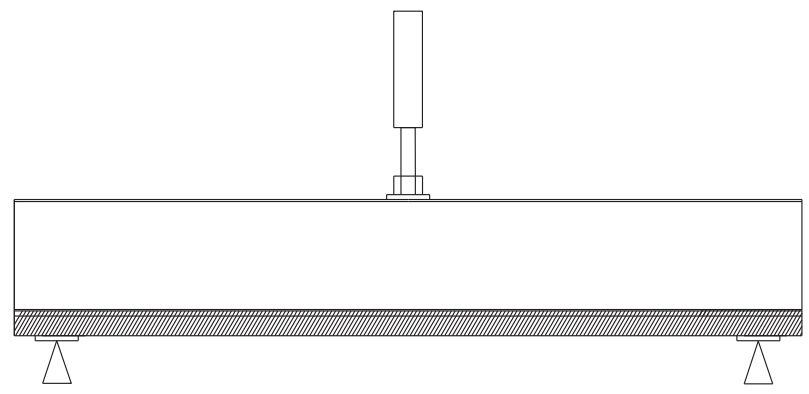

FIgURE 8: Schematic diagram of test beam loading.

$190 \mathrm{kN}$ as maximum load, and the load of each level was $19 \mathrm{kN}$. The upper and lower limits of the dynamic load were $90 \mathrm{kN}-190 \mathrm{kN}$, with the loading frequency being $4 \mathrm{~Hz}$. The specific loading process was as follows: before the dynamic load was applied, three static loads were applied to make the concrete slab crack, so as to simulate the cracked working state of the bridge deck. The dynamic load was stopped every 200,000 cycles, and a static load was applied after each stop to measure strain and deflection and observe cracks. After 1 
million dynamic loads, the load upper limit and load amplitude were gradually increased, and the observation stopped at every 250,000 times until the load fails. The loading scheme is shown in Table 3.

\section{Layout of Measuring Points}

3.1. Layout of Displacement Meter. Figures 9 and 10 show the layout of the combined test beam displacement meter and the micrometer. $\mathrm{P}$ was the deflection displacement meter for measuring the vertical displacement of the whole beam, with an accuracy of $0.01 \mathrm{~mm}$, arranged on the top surface of the concrete beam. $S$ was the dial indicator for measuring slip.

3.2. Layout of Strain Measuring Points. The measuring points of the upper flange were arranged on the bottom of the upper flange and the outside of the box girder. There were strain gauges inside and outside of the web, and the measurement results were checked with each other. The measuring points of the steel beam bottom plate were arranged on the outer side of the bottom, while there were no measuring points on the inner side of the steel beam bottom plate box. Figure 11 shows the layout of the steel beam strain gauge.

PLG-1 was arranged with 5 measuring points at the midspan section, 1 time the beam height, 2 times the beam height, and 3 measuring points at the height of 0.5 times beam height, respectively, at the front and back, a total of 21 measuring points. PLG-2 was equipped with 4 measuring points at each of the 5 sections, with a total of 20 measuring points. Figures 12 and 13 show the measuring points of reinforcement in the concrete bridge panel.

\section{Test Results and Analysis}

4.1. Failure Process and Shape of Test Beam. The loading failure process of the test beams PLG-1 and PLG-2 was roughly the same. During the experiment, there was no obvious slip occurring in both specimens, and the slip measured in static loading was less than $0.02 \mathrm{~mm}$. The concrete slab and the steel flange were always tightly combined and no separation was seen.

In the initial stage of static load loading, the top surface of the concrete slab was pulled apart and cracked. With the increase of load, the distribution range of cracks in the concrete slab increased and the crack width increased. After the first stop under the dynamic load, the crack development range and crack width increased obviously. The main cracks had basically all appeared after the completion of the first dynamic load. In the subsequent fatigue loading, the cracks expanded along the original direction, the width gradually increased with fatigue loading, and the number remained basically unchanged. In the last static test, the width of the crack reached $0.29 \mathrm{~mm}$, which was about $24 \%$ more than before the fatigue loading. Before 750,000 cycles, there was no significant change in deflection. When the static load test was performed after 1 million cycles, the deflection increased significantly compared to before fatigue loading, and the deflection increased by about 17\%. During the loading process, the position of the neutral axis across the midsection had not changed, which means that there was no reduction in stiffness caused by slippage, and the steel beams and steel bars had not reached yield.

After the fatigue failure stopped, the reinforcement at the crack section was observed to be completely fractured. The failure modes of the fractured reinforcement can be divided into two types. The first type was typical fatigue fracture. The second type was the damage caused by the cracks that made the reinforcement enter the plastic phase. The cross section was characterized by uneven stubble and obvious necking. Until the final stage of loading, no bending and shear failure occurred in the shear nails, and no compression failure occurred in the concrete near the shear nails. The failure of PLG-1 is shown in Figure 14.

At the initial stage of PLG-2 loading, the cracks developed to about $0.21 \mathrm{~mm}$ at $200 \mathrm{kN}$. Due to the low load amplitude, the number and spacing of cracks became stable around 600,000 cycles. After loading for 1 million cycles, the crack width increased to $0.27 \mathrm{~mm}$ and the crack width increased by $29 \%$. After 1 million cycles, the maximum crack width also began to increase due to the increase of stress amplitude, and the crack width increased to $0.31 \mathrm{~mm}$ for 1.5 million cycles. There was no significant increase in deflection before 1 million cycles, and it was destroyed after loading 1.65 million cycles. During the 1.5 million shutdown tests, no sudden change in the strain of the steel bars and beams was found.

When the static load before fatigue loading was completed, it was seen that the neutral axis of the midspan section after cracking has been lowered to $150 \mathrm{~mm}$ above the bottom surface, between the first state and the second state. Before 1 million cycles, the position of the neutral axis across the midsection had not changed, indicating that there was no decrease in stiffness due to slippage and that the steel beams and reinforcement did not yield. When the load reached 1 million cycles, the neutral axis position dropped to about $200 \mathrm{~mm}$, indicating that the bonding and slip performance of the reinforcement weakened and the section stiffness decreased. When loaded to about 1.62 million cycles, an opening crack of about $3 \mathrm{~mm}$ appeared. Fatigue fracture of some reinforcement had occurred at the crack, and the connection between the concrete slab and the steel flange was still intact. At this time, the load was continued without stopping, and the crack developed rapidly. As the cracks developed, the tension released by the concrete slab was shared by the remaining ordinary reinforcement and the upper flange of the steel beam. The ordinary reinforcement in concrete slab was first tensioned to yield and the displacement amplitude increased obviously. Then the reinforcement in the concrete slab at the centerline broke, followed by the flange crack on the steel beam, and the cracks gradually spread to the web of the steel beam and stopped at 1.65 million cycles.

After the shutdown, it was observed that the reinforcement was completely broken at the crack section, and the fracture form of the broken reinforcement was the same as PLG-1. Until the final stage of loading, there was no bending and shear failure of the shear nails, and there was no compression failure of the concrete near the shear nails. The damage of PLG-2 is shown in Figure 15. 
TABle 3: Test load.

\begin{tabular}{cccccc}
\hline \multicolumn{2}{c}{ Specimen } & PLG-1 & PLG-2 $\left(0-1 \times 10^{6}\right.$ cycles $)$ & PLG-2 $\left(1 \times 10^{6}-1.5 \times 10^{6}\right.$ cycles $)$ & PLG-2 (after $1.5 \times 10^{6}$ cycles $)$ \\
\hline \multirow{4}{*}{ Load $(\mathrm{kN})$} & Upper limit & 490 & 190 & 300 & 380 \\
& Lower limit & 225 & 90 & 90 & 130 \\
& Amplitude & 265 & 100 & 210 & 250 \\
\hline
\end{tabular}

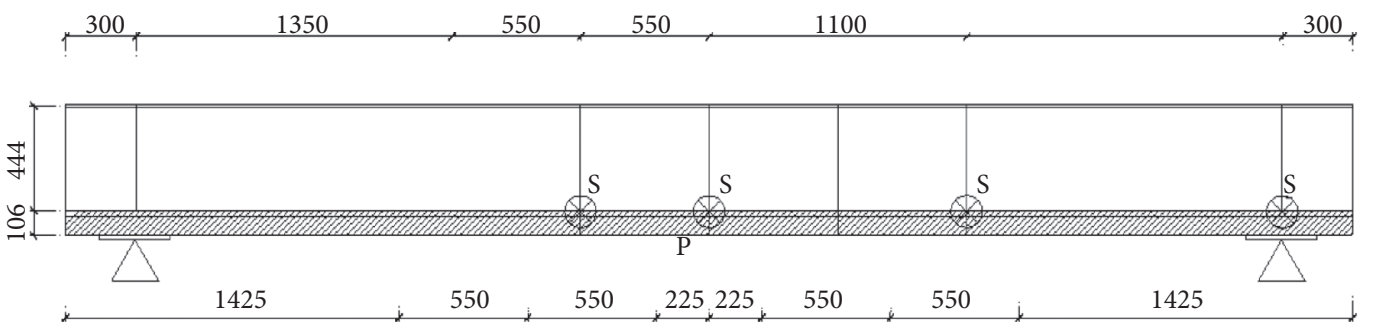

FIgURE 9: Layout on the left (unit: mm).

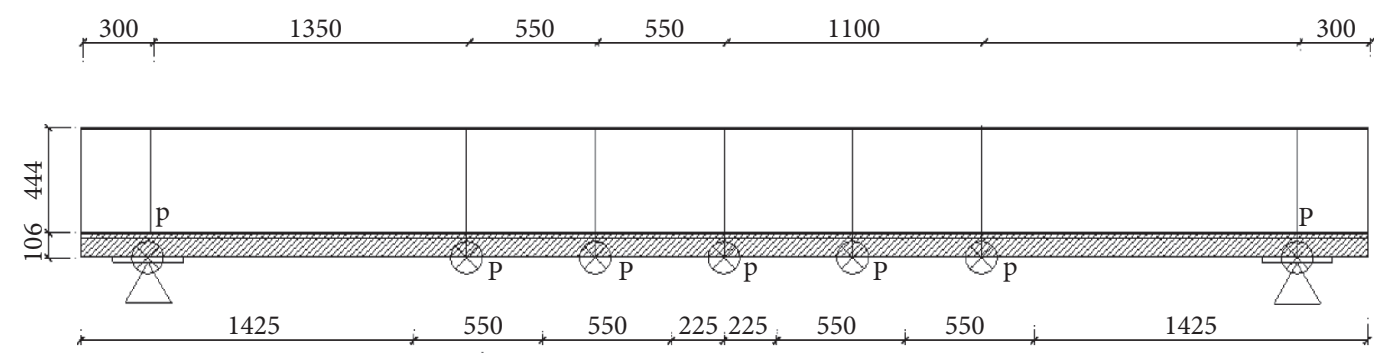

FIgURE 10: Layout on the right (unit: mm).

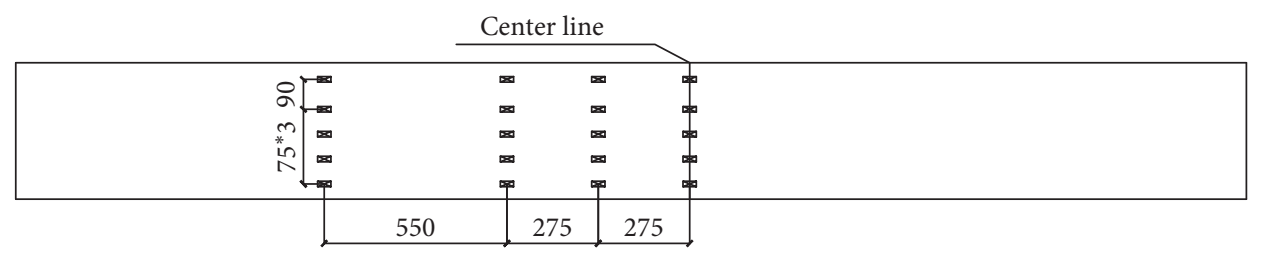

(a)

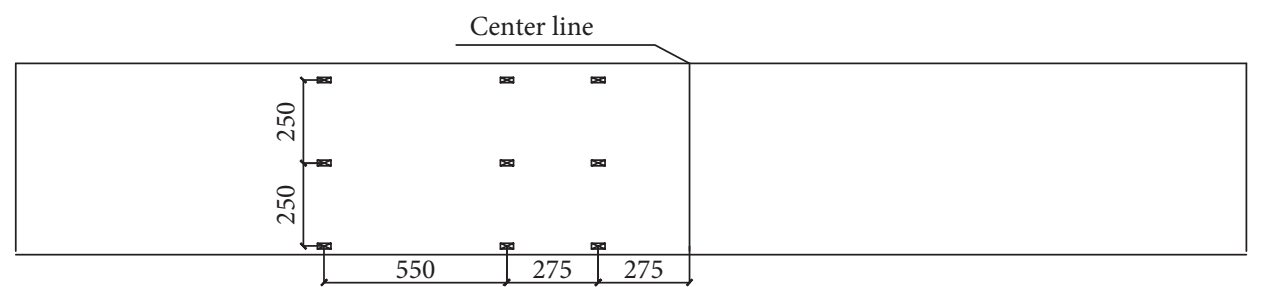

(b)

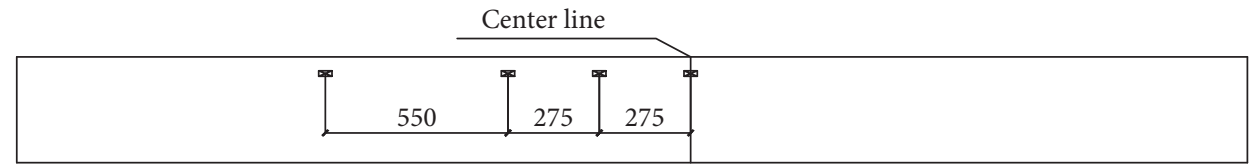

(c)

FIGURE 11: Layout of measuring points of steel beam (unit: $\mathrm{mm}$ ). (a) Layout of inner and outer webs. (b) Layout of outside of base plate. (c) Layout of lower side of upper flange. 


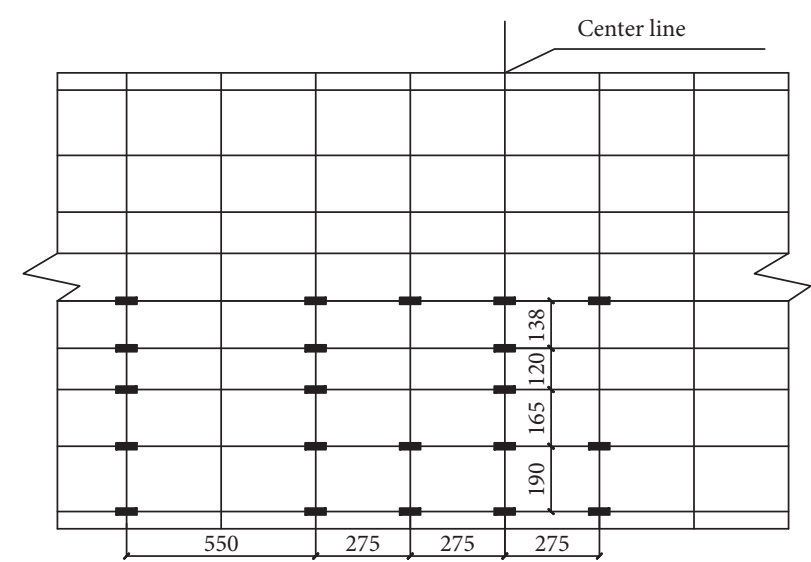

FIGURE 12: Layout of PLG-1 reinforcement measuring point (unit: $\mathrm{mm}$ ).

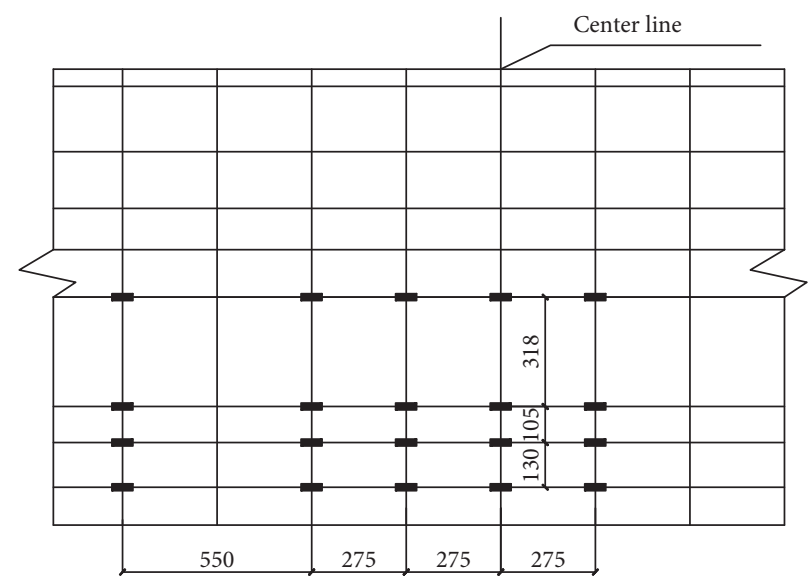

FIGURE 13: Layout of PLG-2 reinforcement measuring point (unit: mm).

\subsection{Cracks in Concrete Slab}

4.2.1. PLG-1. After the initial static load of PLG-1, the cracks were mainly concentrated in the range of 2.5 times the beam height on both sides of the center line. The maximum crack width was $0.25 \mathrm{~mm}$, and the main through crack distance was about $14 \mathrm{~cm}$. After 250,000 cycles, the crack expanded to 3.5 times the beam height on both sides of the centerline, and the maximum width of the crack reached $0.26 \mathrm{~mm}$. After 500,000 cycles, 750,000 cycles, and 1 million cycles, the range of crack distribution and the maximum crack width changed little, which was the penetration and widening of the original crack. Before fatigue failure, the maximum crack width increased by about $24 \%$. The crack width information of the test beam is summarized in Table 4. Figures 16 and 17 show the crack distribution diagram of PLG-1 concrete slab and the photos of the crack with the maximum width.

4.2.2. PLG-2. After the initial static load, five cracks appeared within a range of 1 time the beam height from the centerline, and the maximum width of the initial crack was $0.21 \mathrm{~mm}$. After 200,000 cycles, several new cracks appeared, and the cracks were mainly concentrated within the double beam height on both sides of the middle fulcrum. After 400,000 cycles, several new cracks appeared within the original cracks. After 600,000 cycles, the number and length of cracks had developed greatly. The cracks were mainly concentrated in the range of 2.5 times the beam height on both sides of the middle fulcrum, and many cracks penetrated the plate width. After 800,000 cycles and 1 million cycles, the range of crack distribution and the maximum crack width changed little, basically the penetration and widening of the original cracks. When the load did not increase, the crack width increased by $29 \%$ after 1 million cycles. After increasing the upper limit of the load and the amplitude of the load, during the 1.25 million shutdown observations, several through cracks appeared, and the main cracks were concentrated within 3.5 times the beam height on both sides of the center line. After 1.5 million cycles, the distribution range and length of the cracks were similar to those after 1.25 million cycles, and some cracks had developed. The crack width information of the test beam is summarized in Table 5. Figures 18 and 19 show the crack distribution diagram of PLG-2 concrete slab and the photos of the crack with the maximum width. 


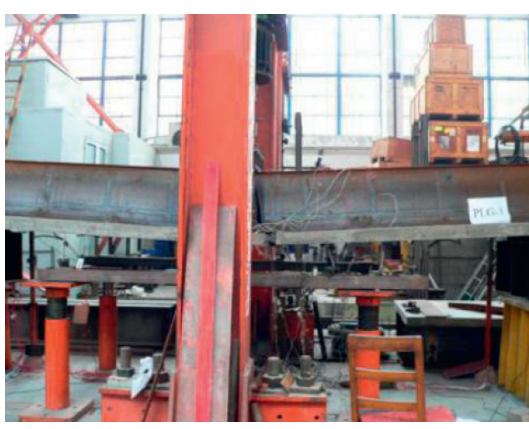

(a)

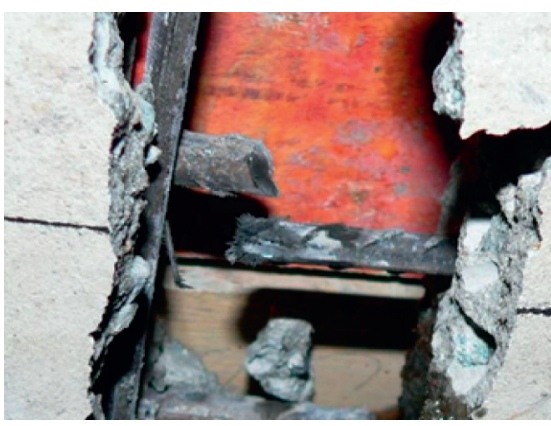

(b)

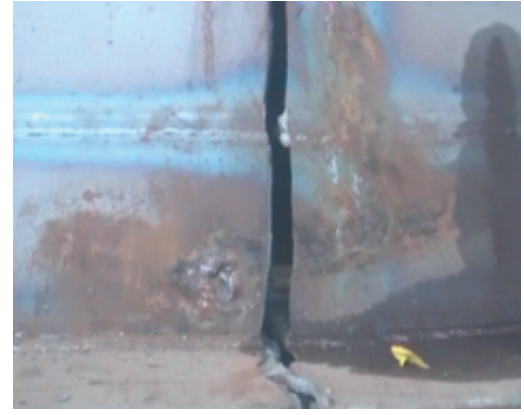

(c)

Figure 14: Failure mode of PLG-1. (a) Global failure of composite beam. (b) Failure of reinforcement. (c) Failure of steel beam.

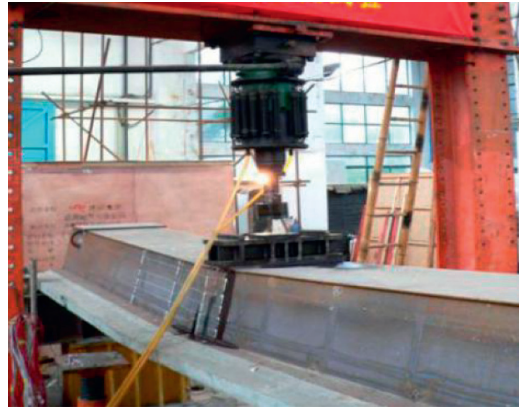

(a)

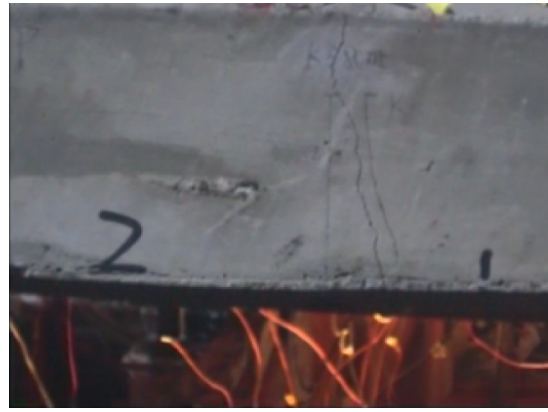

(b)

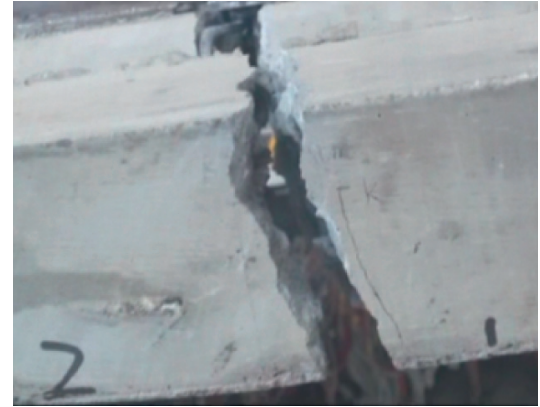

(c)

FIgURE 15: Failure mode of PLG-2. (a) Global failure of composite beam. (b) Crack of concrete slab. (c) Failure of concrete slab.

TABLE 4: Cracks of concrete slab of PLG-1 (unit: mm).

\begin{tabular}{lcccccc}
\hline PLG-1 & $\begin{array}{c}\text { Before the dynamic } \\
\text { load }\end{array}$ & $\begin{array}{c}\text { Before the dynamic } \\
\text { load }\end{array}$ & $\begin{array}{c}\text { After 250,000 } \\
\text { cycles }\end{array}$ & $\begin{array}{c}\text { After 250,000 } \\
\text { cycles }\end{array}$ & $\begin{array}{c}\text { After 250,000 } \\
\text { cycles }\end{array}$ & $\begin{array}{c}\text { After 1 million } \\
\text { cycles }\end{array}$ \\
\hline $\begin{array}{l}\text { Static load } \\
\text { (kN) }\end{array}$ & 380 & 490 & 490 & 490 & 490 & 490 \\
Crack width & 0.22 & 0.25 & 0.26 & 0.27 & 0.29 & 0.31 \\
\hline
\end{tabular}

\subsection{Load-Displacement Curve}

4.3.1. PLG-1. Before the dynamic load was applied, the static load was applied to the test beam first. The static load was divided into ten levels; each level was $49 \mathrm{kN}$. The load-displacement curve under static load of PLG-1 is shown in Figure 20. It can be seen from the figure that the concrete cracked when the displacement was small, the cracking load was approximately $100 \mathrm{kN}$. After cracking, the slope of the load-displacement curve decreased, indicating that the stiffness of the test beam decreases gradually. The static loading before fatigue loading reached a maximum displacement of about $7.0 \mathrm{~mm}$ at $500 \mathrm{kN}$.

As can be seen from Figure 21, the load-displacement curves of PLG-1 in static load test after each fatigue load showed a linear relationship. Before the occurrence of fatigue failure, the midspan deflection did not change significantly under the same static load, within $1 \mathrm{~mm}$. It was shown that there is no significant stiffness decrease of PLG-1 test beam before fatigue failure.
4.3.2. PLG-2. Before dynamic load was applied, static load was applied to the test beam. There were ten stages of static load, each of which is $20 \mathrm{kN}$. The load-displacement curve under static load is shown in Figure 22. It can be seen that concrete cracks occurred when the displacement was very small, and the cracking load was about $48 \mathrm{kN}$, which decreased by $52 \%$ compared with PLG-1. The static loading before fatigue loading reached a maximum displacement of about $2.5 \mathrm{~mm}$ at $200 \mathrm{kN}$.

As can be seen from Figure 23, the load-displacement curves of PLG-2 in static load test after each fatigue load showed a linear relationship. Under the same static load, the deflection in the span did not change much. The static test displacement after 1 million times increased by $1.6 \%$ compared with the deflection before dynamic loading, but the deflection after 1.25 million times increased by $46 \%$ and the deflection after 1.5 million times increased by $60 \%$, indicating that the stiffness of the beam decreased significantly shortly before fatigue failure. Compared with PLG-1, the stiffness of PLG-2 under fatigue load decreased more significantly before fatigue failure. 


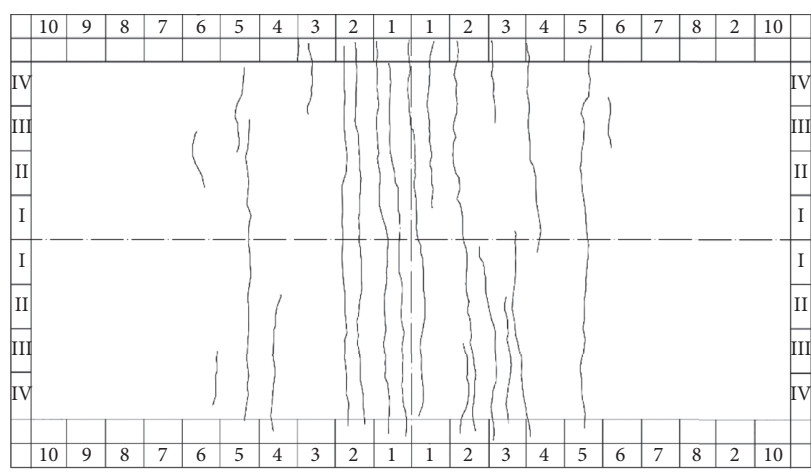

(a)

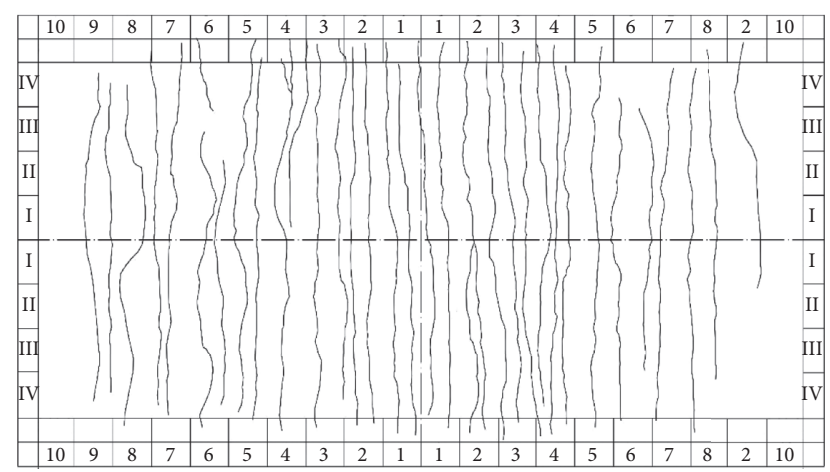

(b)

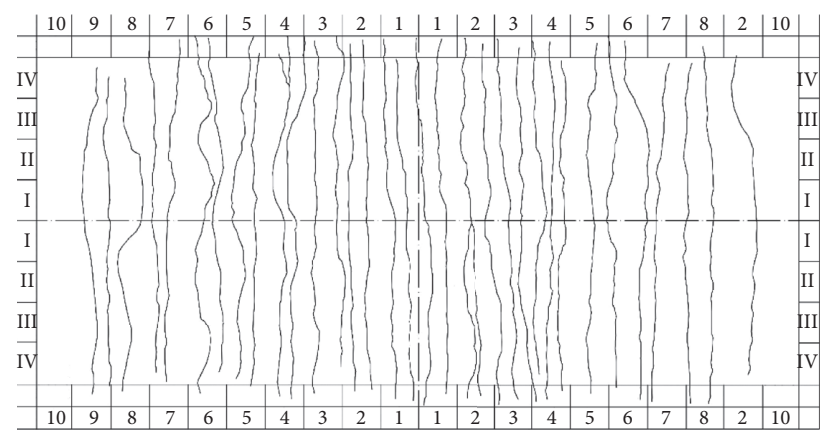

(c)

Figure 16: Distribution of cracks in the concrete slab of PLG-1. (a) $380 \mathrm{kN}$. (b) After 250,000 cycles. (c) After 1 million cycles.

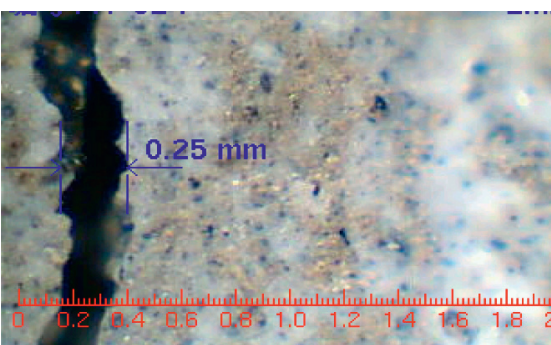

(a)

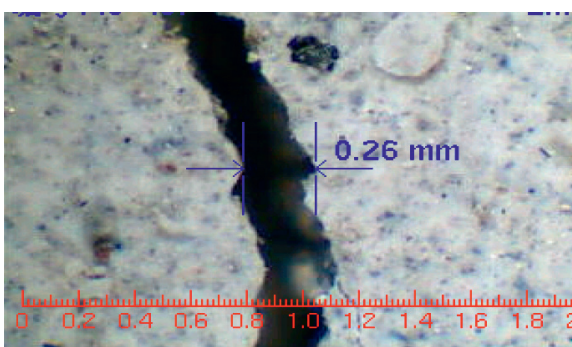

(b)

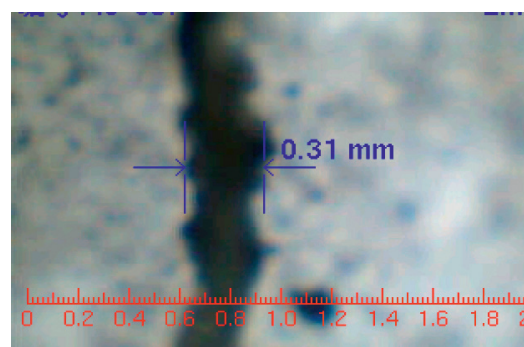

(c)

FIgURE 17: The largest crack in the concrete slab of PLG-1. (a) $380 \mathrm{kN}$. (b) After 250,000 cycles. (c) After 1 million cycles.

TABLE 5: Cracks of concrete slab of PLG-2 (unit: $\mathrm{mm}$ ).

\begin{tabular}{lcccccccc}
\hline PLG-2 & $\begin{array}{c}\text { Before the } \\
\text { dynamic load }\end{array}$ & $\begin{array}{c}\text { After 200,000 } \\
\text { cycles }\end{array}$ & $\begin{array}{c}\text { After 400,000 } \\
\text { cycles }\end{array}$ & $\begin{array}{c}\text { After 600,000 } \\
\text { cycles }\end{array}$ & $\begin{array}{c}\text { After 800,000 } \\
\text { cycles }\end{array}$ & $\begin{array}{c}\text { After 1 } \\
\text { million cycles }\end{array}$ & $\begin{array}{c}\text { After } 1.25 \\
\text { million cycles }\end{array}$ & $\begin{array}{c}\text { After } 1.5 \\
\text { million cycles }\end{array}$ \\
\hline $\begin{array}{l}\text { Static load } \\
\text { (kN) }\end{array}$ & 190 & 190 & 190 & 190 & 190 & 190 & 300 & 380 \\
$\begin{array}{l}\text { Crack } \\
\text { width }\end{array}$ & 0.21 & 0.23 & 0.25 & 0.26 & 0.27 & 0.27 & 0.29 & 0.32 \\
\hline
\end{tabular}

4.4. Reinforcement Strain of Concrete Slab. The strain of upper reinforcement at the center line of PLG-1 and PLG-2 was selected for analysis. Figure 24 shows the midspan reinforcement strain of PLG-1 after 1 million dynamic loaded. It can be seen that the reinforcement strain at the top of the web was larger than that at the other positions, indicating a shear lag effect existence, but the effect was not obvious. Figure 25 shows the strain of the midspan reinforcement of PLG-2 after 1.25 million dynamic loaded, and it was not found that the strain of the web reinforcement was 


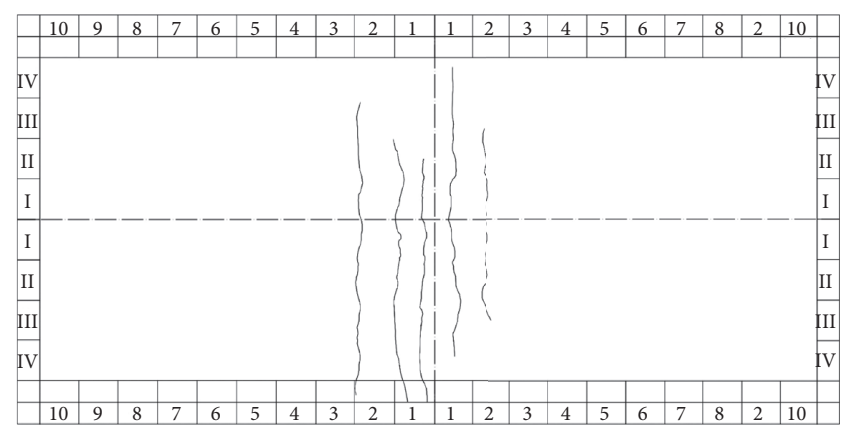

(a)

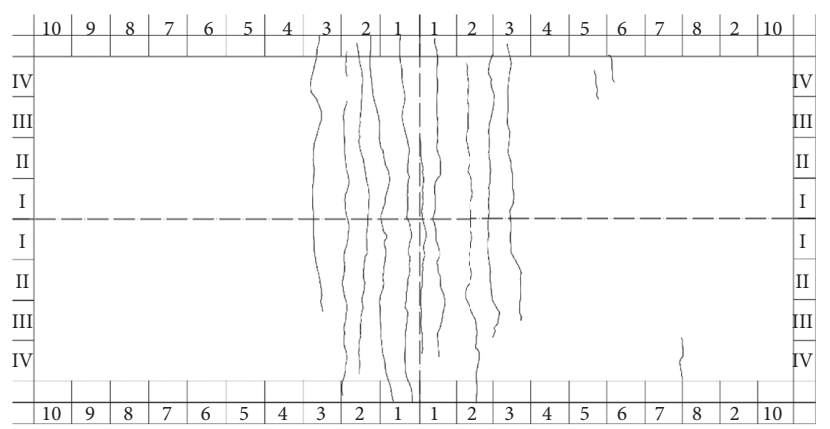

(b)

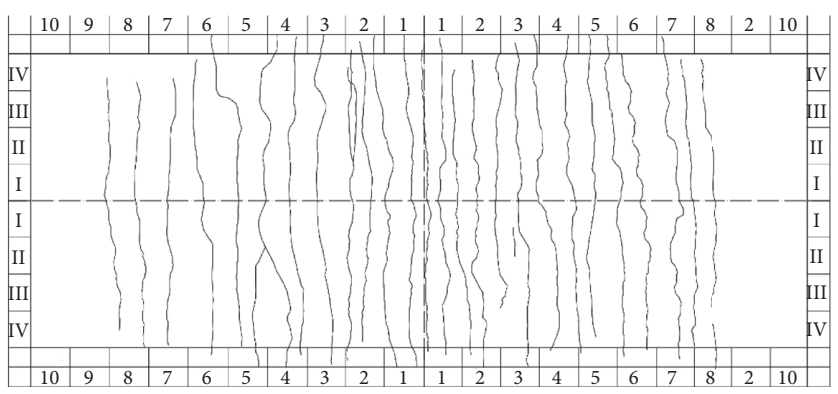

(c)

Figure 18: Distribution of cracks in the concrete slab of PLG-2. (a) $200 \mathrm{kN}$. (b) After 200,000 cycles. (c) After 1.5 million cycles.

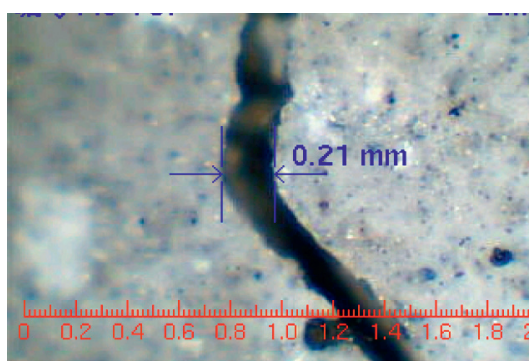

(a)

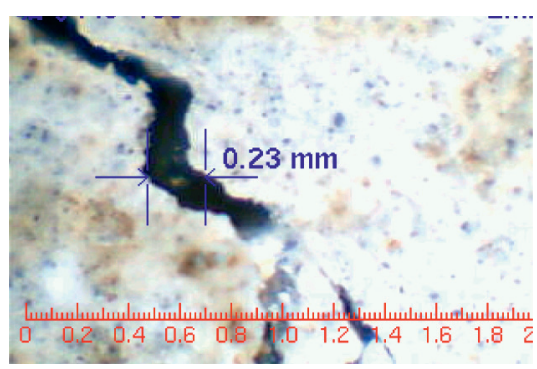

(b)

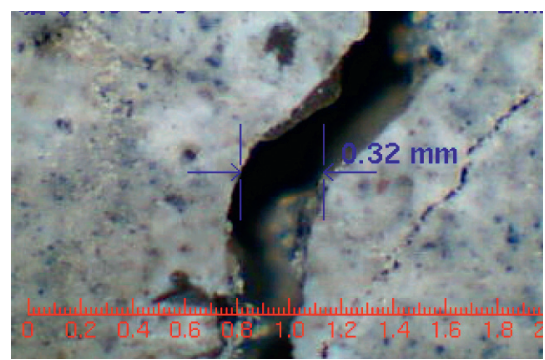

(c)

Figure 19: The largest crack in the concrete slab of PLG-2. (a) $200 \mathrm{kN}$. (b) After 200,000 cycles. (c) After 1.5 million cycles.

larger than that of the rest positions, which might be caused by the low reinforcement ratio of PLG-2, the insignificant shear lag effect, or the limited means of test. Figures 26 and 27 show the variation curve and comparison curve of reinforcement strain in concrete slab with load at the center line of PLG -1 and PLG -2. It can be seen that the strain of the reinforcement during the initial cracking of the concrete was greater than the strain of the reinforcement during repeated loading, which might be caused by the decrease in the stiffness of the concrete caused by repeated loading and the reduction of the shared moment of the concrete slab. Due to the influence of cracks, the strain of steel bars collected by strain gauge at the same section location was not the same. After the cracking of concrete, the load-strain relationship of reinforcement was close to linear in each static loading after repeated loading.

\subsection{Strain of Steel Beam}

4.5.1. PLG-1. Figure 28 shows the relationship between strain and load on the top flange of the steel beam at the center line section and at 0.5 times the beam height. It can be seen that the effect of fatigue load on the stiffness of the steel 


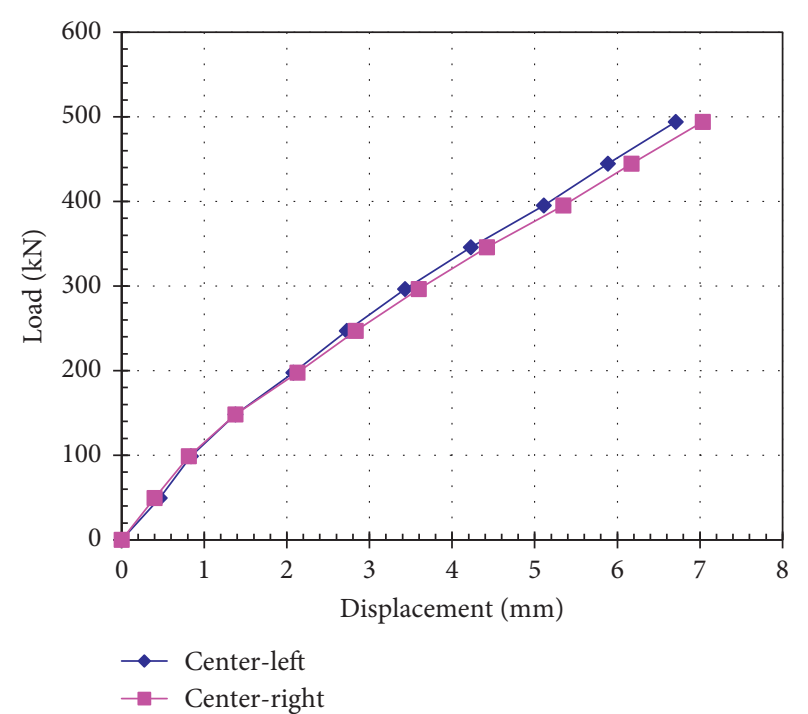

FIgURe 20: Load-displacement curve of PLG-1 midspan (before dynamic load).

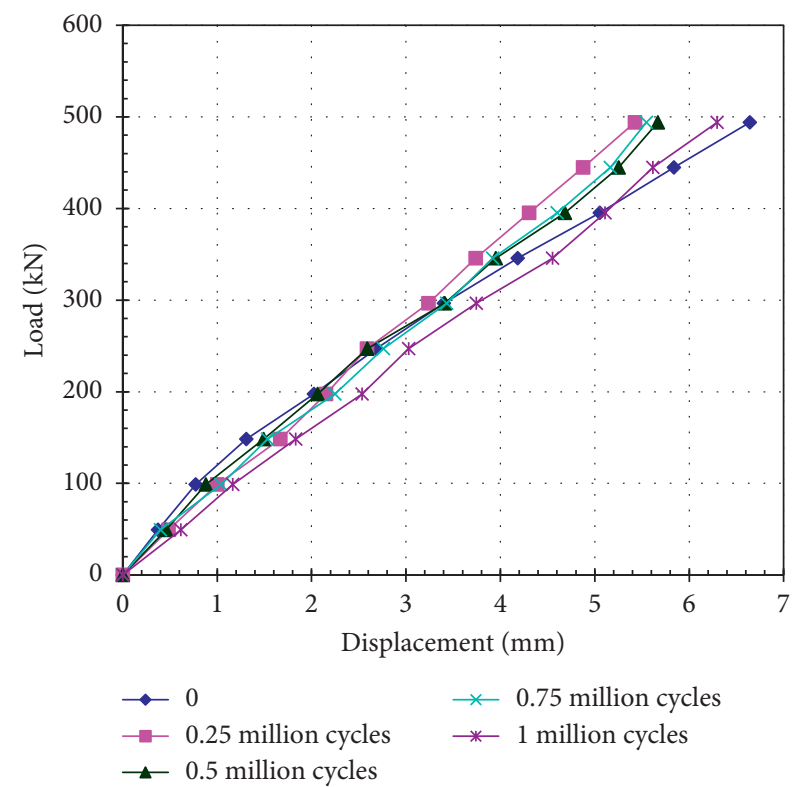

Figure 21: Comparison of midspan load-displacement curves (after dynamic loading of PLG-1).

beam was not obvious. After the first static load cracking of the concrete slab, the strain-load of the steel beam had a linear relationship and was in a lower stress state. With the increase of fatigue loading times, the strain of steel beam under the same load increases gradually.

Figure 29 shows the relationship between strain and section height on the top flange of the steel beam at the center line section and at 0.5 times the beam height. As can be seen from the figure, along the height of the section, the various strains were distributed in proportion to the distance

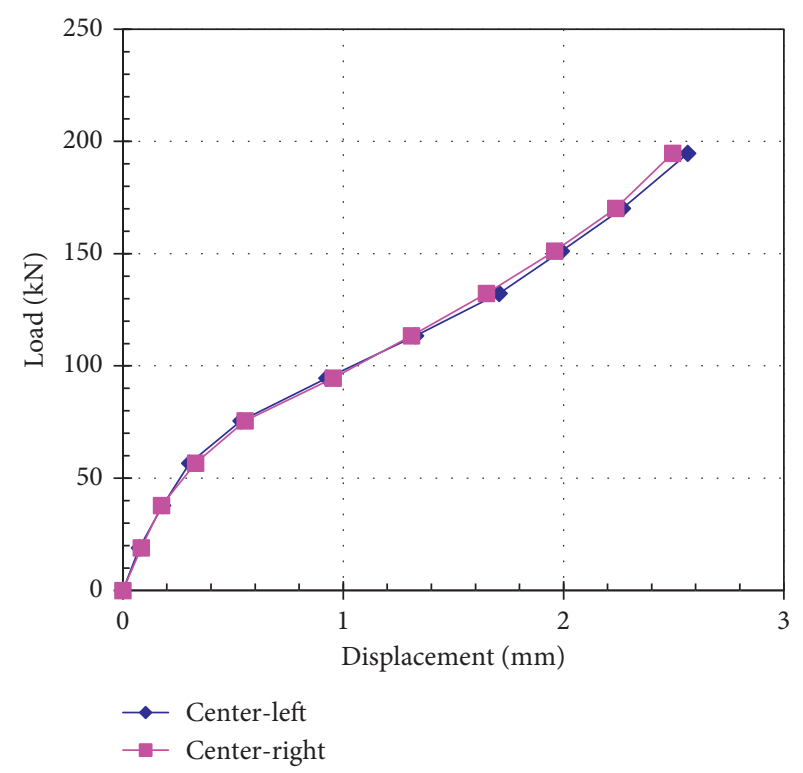

FIGURE 22: Load-displacement curve of PLG-2 midspan (before dynamic load).

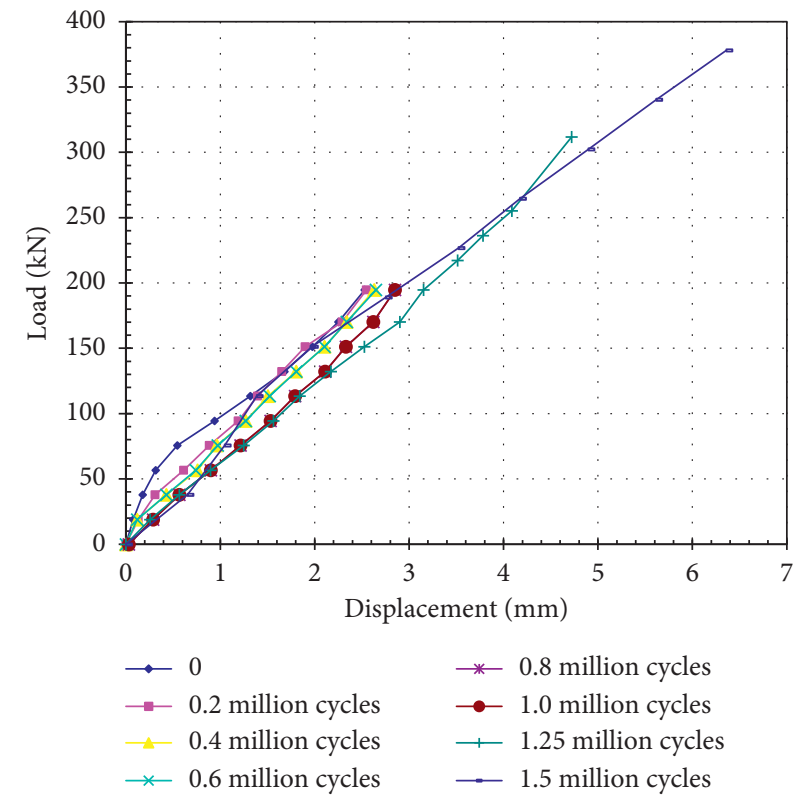

FIgURE 23: Comparison of midspan load-displacement curves (after dynamic loading of PLG-2).

from the neutral layer. As the load increases step by step, the strain was distributed in a straight line. The neutral layer was $150 \mathrm{~mm}$ away from the bottom edge of the section. After 1 million cycles, it can be seen that the strain at the height of $450 \mathrm{~mm}$ was basically the same, and the strain value at the 0.5 times beam height at the height of $0 \mathrm{~mm}$ was about twice the strain value of the central line section. The steel beam was in the elastic working range, and the section deformation conforms to the assumption of flat section. 


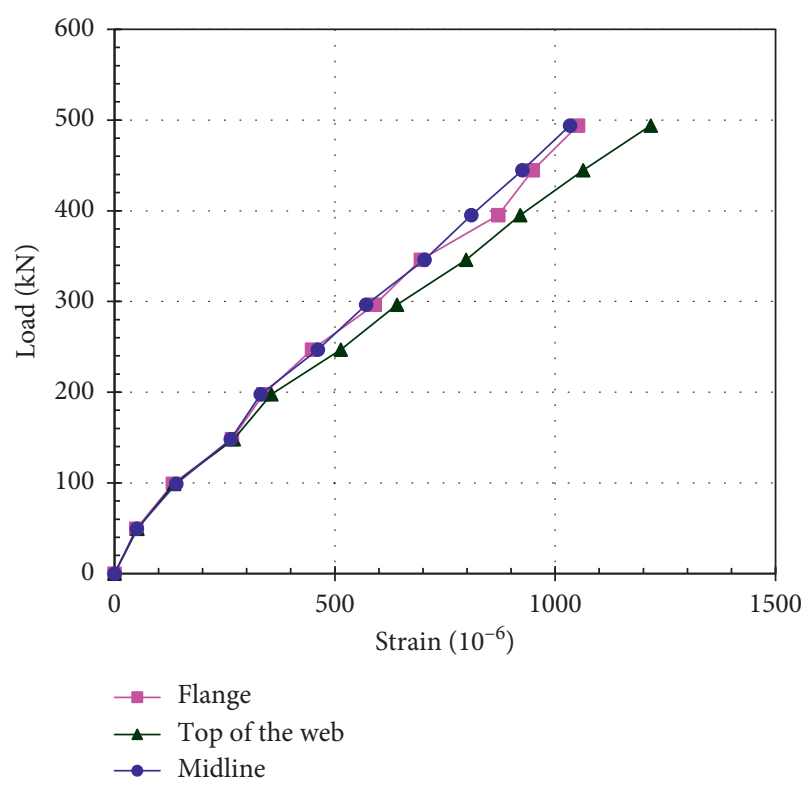

Figure 24: PLG-1 strain of midspan reinforcement after 1 million dynamic loads.

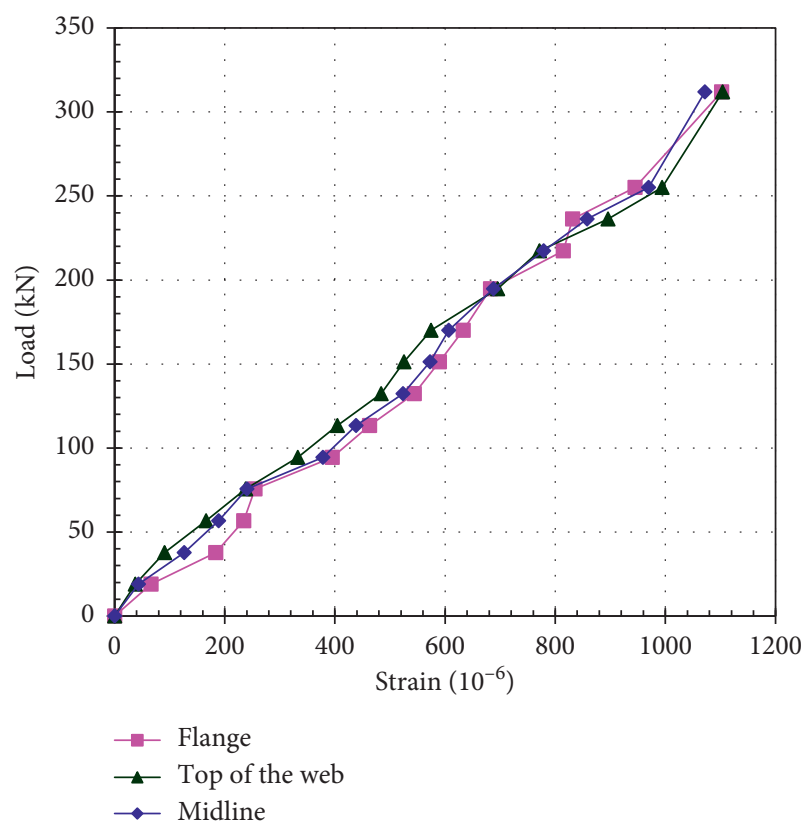

FIGURE 25: PLG-2 strain of midspan reinforcement after 1.25 million dynamic loads.

4.5.2. PLG-2. Figure 30 shows the variation curve of top flange strain with load at the center line section and 0.5 beams height section of PLG-2. It can be seen that the strain of the steel beam was not affected by the fatigue load. The load-strain relationship of steel beams after fatigue loading was linear. As the cycles of loadings increased, the strain of the steel beam under the same load gradually increased. Under the same static load, the strain after 1 million cycles of

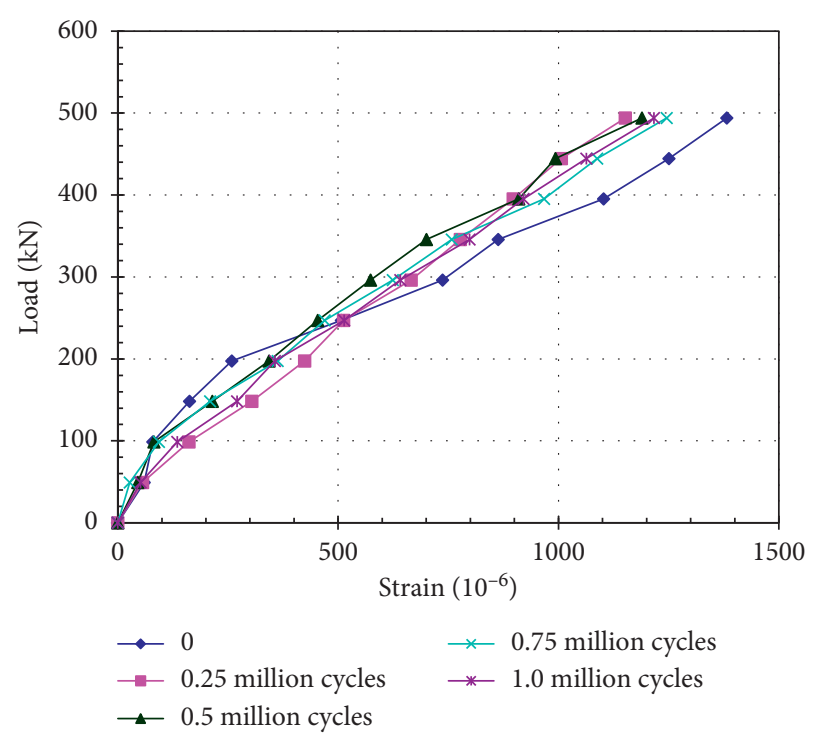

FIGURE 26: PLG-1 reinforcement strain comparison of midspan concrete slab.

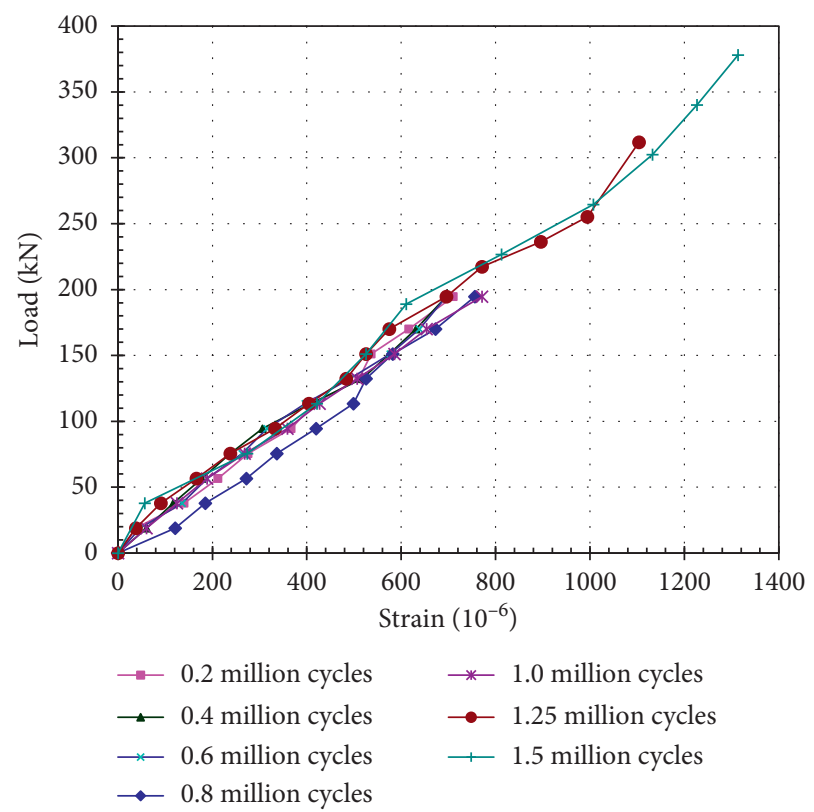

FIGURE 27: PLG-2 reinforcement strain comparison of midspan concrete slab.

fatigue loading increased by $2 \%$ compared with that after 200,000 cycles, but the strain after 1.25 million cycles of loading increased by $40 \%$ and that after 1.5 million cycles of loading increased by $50 \%$, indicating that the rigidity of the steel beam before fatigue failure was significantly reduced.

Figure 31 shows the relationship between strain and section height on the top flange of the steel beam at the center line section and at 0.5 times the beam height. As can be seen from the figure, along the height of the section, the 


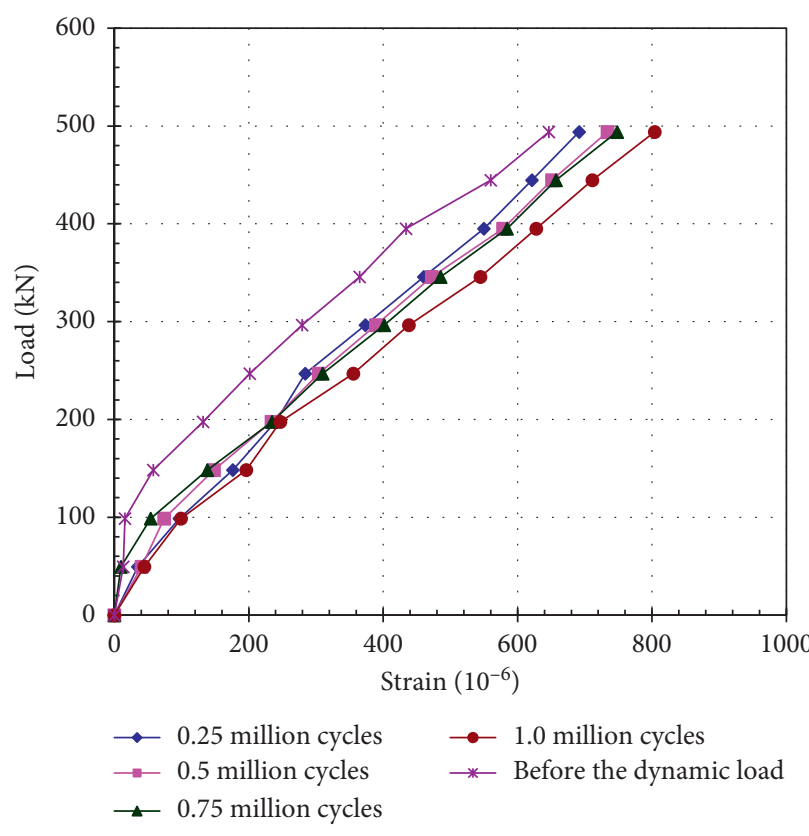

(a)

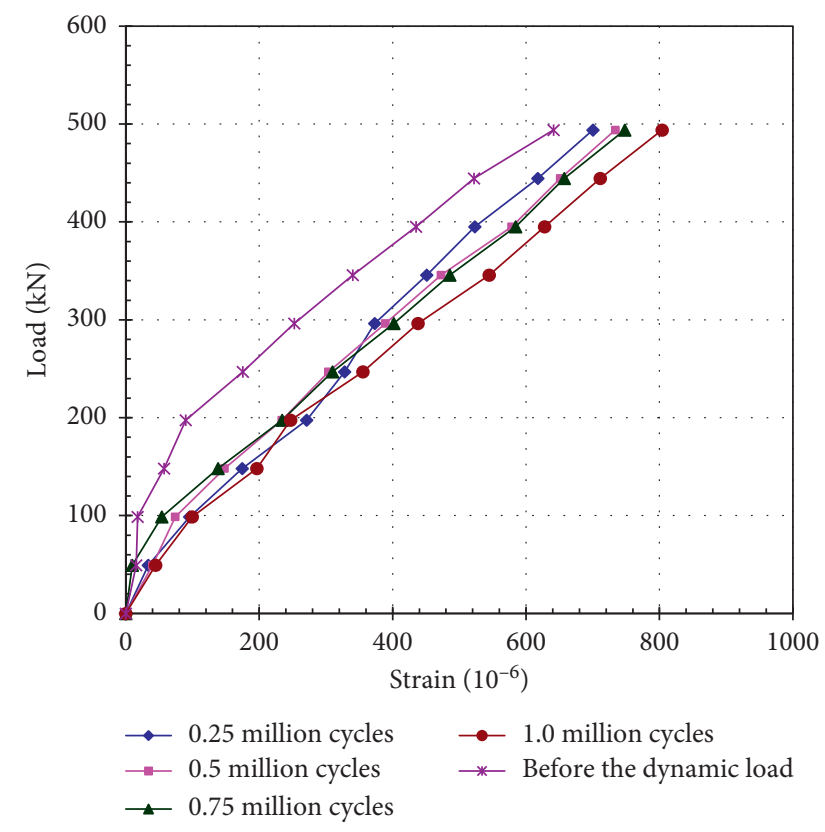

(b)

Figure 28: Curve of strain of PLG-1 steel beam with load. (a) Center line section. (b) 0.5 times the beam height section.

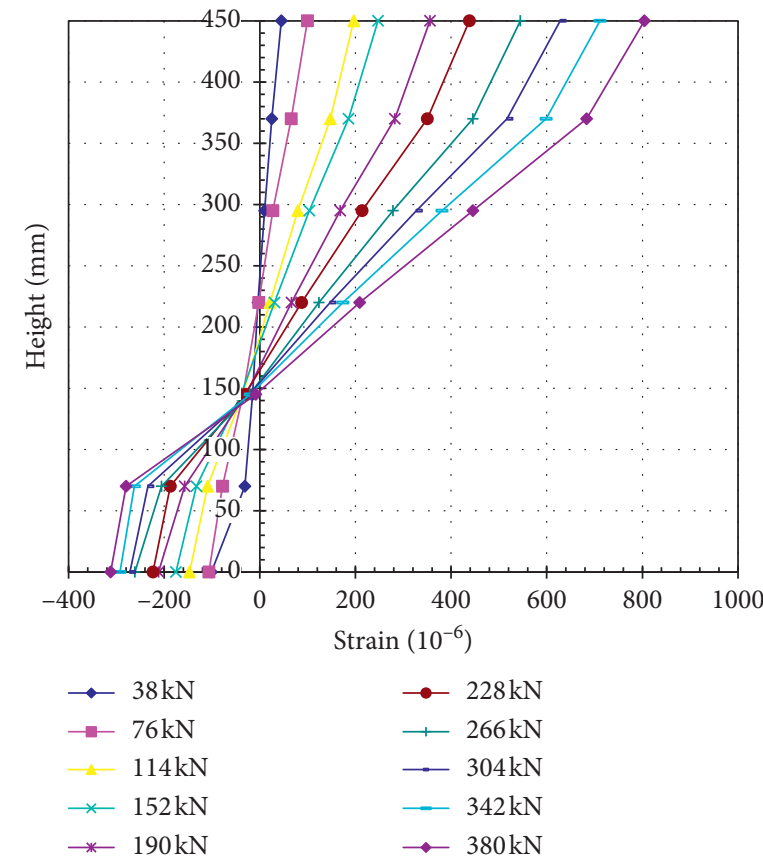

(a)

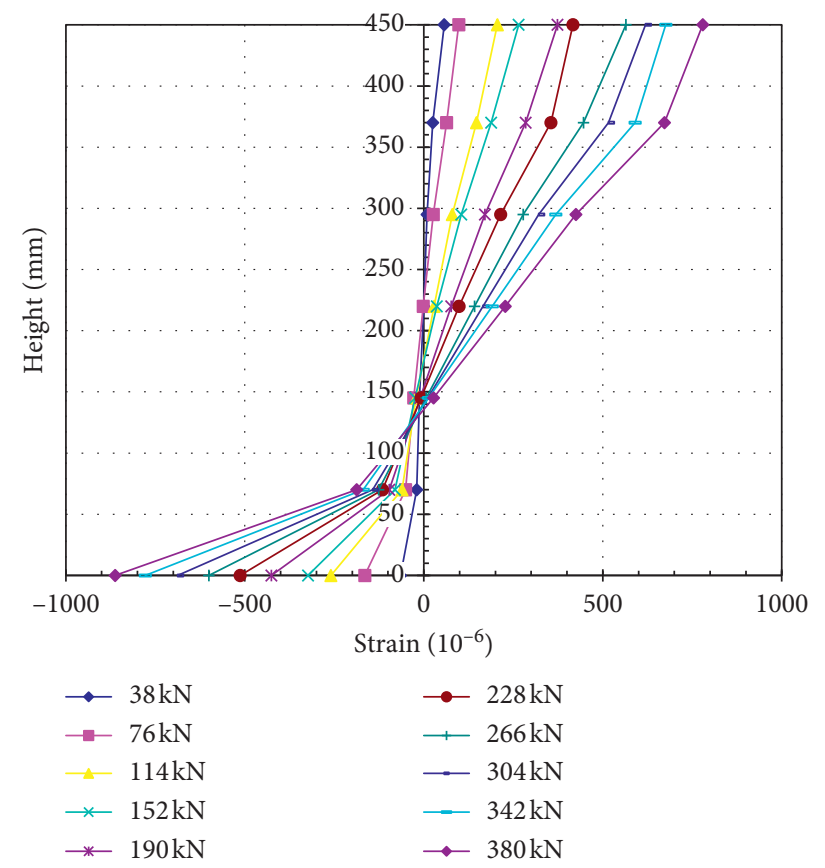

(b)

Figure 29: Curve of strain of PLG-1 steel beam with height. (a) Center line section (after 1 million cycles). (b) 0.5 times the beam height section (after 1 million cycles).

various strains were distributed in proportion to the distance from the neutral layer. As the load increases step by step, the strain was distributed in a straight line. The neutral layer was $150 \mathrm{~mm}$ away from the bottom edge. After 1 million cycles, it can be seen that the strain at the height of $450 \mathrm{~mm}$ was basically the same, and the strain value at the 0.5 times beam height at the height of $0 \mathrm{~mm}$ was about 1.5 times the strain value of the central line section. The steel beam was in the elastic working range, and the section deformation conforms to the assumption of flat section. 


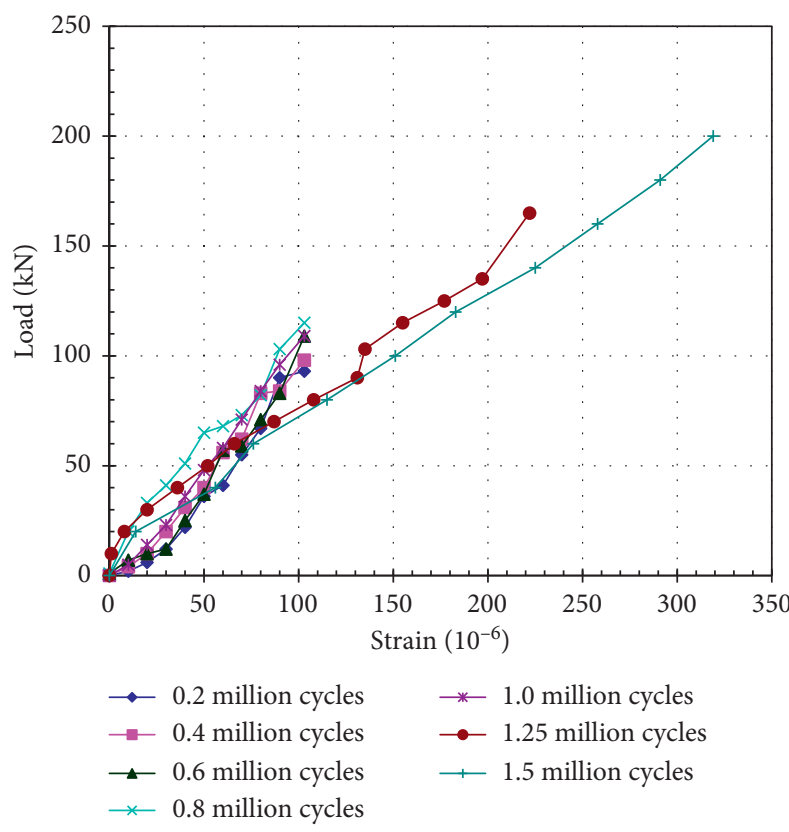

(a)

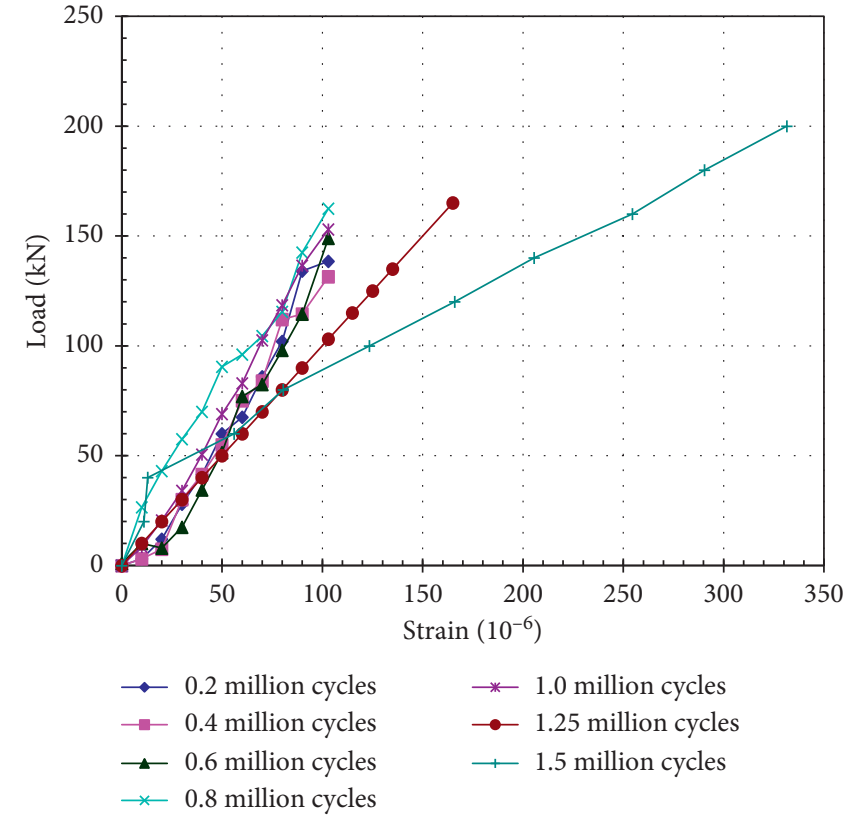

(b)

Figure 30: Curve of strain of PLG-2 steel beam with load. (a) Center line section. (b) 0.5 times the beam height section.

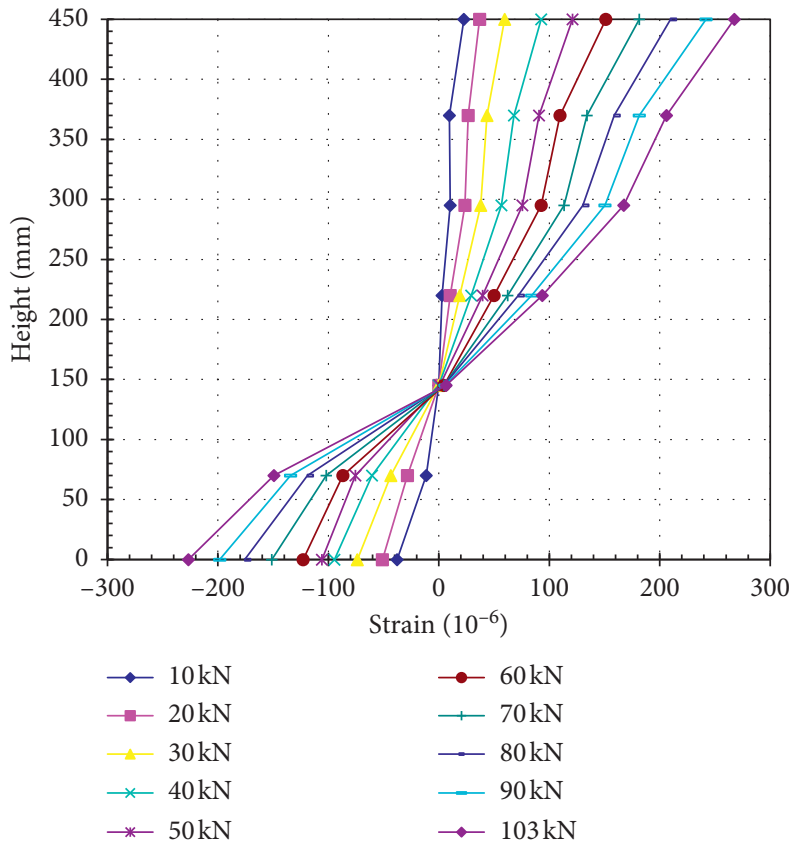

(a)

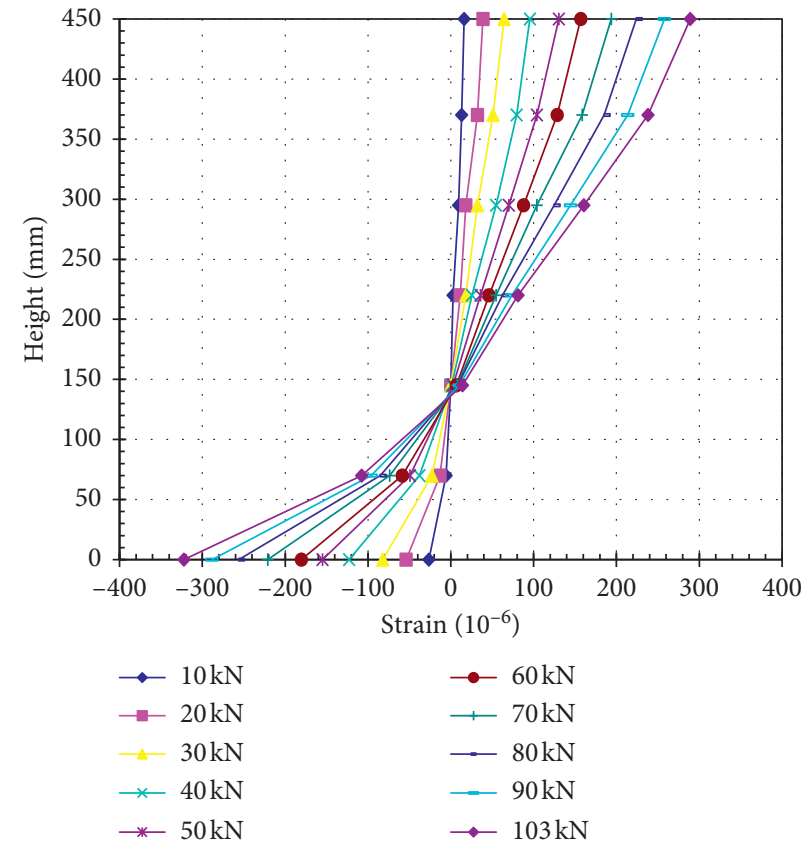

(b)

Figure 31: Curve of strain of PLG-2 steel beam with height. (a) Center line section (after 1 million cycles). (b) 0.5 times the beam height section (after 1 million cycles).

\section{Conclusions}

This work presents the results of the fatigue test and theoretical analysis of two composite beams with different reinforcement ratios used to obtain the variation law of the deflection, steel bar strain, steel beam strain, and crack growth of the composite beam under fatigue loading. Based on the experimental and theoretical results the following conclusions can be drawn:

(1) The failure modes of the composite beams with two reinforcement ratios designed in this paper were typical fractures of reinforcement, and there was no fatigue damage to the wailing nails and steel flange. The 
cracking of the concrete in the negative moment region of the composite beam and the combined action between steel and concrete were not obvious, and the stress on the welding nails was small. However, there was stress concentration in the reinforcement at the crack, and the fatigue failure in the negative moment region of a composite beam was likely to be controlled by reinforcement, but welding nails.

(2) The reinforcement ratio of the concrete slab had little effect on the cracking load and crack distribution range of the test beam but had a greater effect on the crack width and crack spacing. The higher the concrete reinforcement ratio, the smaller crack distribution range, the denser crack spacing, and the smaller crack width.

(3) During the whole process of fatigue loading, the crack width growth trend of specimens with different reinforcement ratios was close to each other. When the reinforcement ratio of composite beams increased from $0.86 \%$ to $1.72 \%$, the maximum crack width before fatigue failure decreases from $28 \%$ to $24 \%$ after one million times of fatigue tests. The fatigue resistance of the low reinforcement ratio specimen was much lower than the high reinforcement ratio specimen.

(4) The strains of the reinforcement and steel beams during the initial cracking were higher than those after repeated loading, and the stress concentration of reinforcement in the initial cracking was higher than that after repeated loading. As the number of loadings increases, the strain of the steel beam increased and the strain of the steel bar decreased; the internal force redistribution occurred in the section.

\section{Data Availability}

The data used to support the findings of this study are not available.

\section{Conflicts of Interest}

All authors declare that there are no conflicts of interest regarding the publication of this article.

\section{Acknowledgments}

This work was supported by the National Natural Science Foundation of China (no. 51878623), Innovative Research Team (in Science and Technology) in University of Henan Province (Grant no. 20IRTSTHN009), Program for Young Backbone Teachers in Colleges and Universities in Henan, (2018GGJS005), and Foundation for Postdoctoral Students in Henan Province (1901024).

\section{References}

[1] R. P. Johnson, Composites Structures of Steel and Concrete: Beams, Slabs, Columns, and Frames for Buildings, WileyBlackwell, Hoboken, NY, USA, 3rd edition, 2004.
[2] K. Rajan, "The study on flexural behavior of steel-concrete composite continuous box girder," M.S. thesis, Southeast University, Nanjing, China, 2019.

[3] F. Ding, J. Liu, and X. Liu, "Experimental investigation on hysteretic behavior of simply supported steel-concrete composite beam," Journal of Constructional Steel Research, vol. 144, pp. 153-165, 2018.

[4] J. Fan, J. Nie, H. Wang, and Q. Li, "Long-term behavior of composite beams under positive and negative bending I: experimental study," Journal of Structural Engineering, vol. 136, no. 7, pp. 849-857, 2010.

[5] P. Zhang, Y.-n. Zhao, C.-h. Liu, P. Wang, and T.-h. Zhang, "Combined effect of nano- $\mathrm{SiO}_{2}$ particles and steel fibers on flexural properties of concrete composite containing fly ash," Science and Engineering of Composite Materials, vol. 21, no. 4, pp. 597-605, 2014.

[6] S. Han, Y. Cui, H. Huang, M. An, and Z. Yu, "Effect of curing conditions on the shrinkage of ultra high-performance fiberreinforced concrete," Advances in Civil Engineering, vol. 2018, Article ID 5238278, pp. 1-8, 2018.

[7] P. R. Barnard and R. P. Johnson, "Plastic behavior of continuous composite beams," Proceedings of the Institution of Civil Engineers, vol. 32, no. 2, pp. 180-197, 1965.

[8] S. K. Mallick and S. K. Chattopadhyay, "Ultimate strength of continuous composite beams," Building Science, vol. 10, no. 3 , pp. 189-198, 1975.

[9] S. Hamada and J Longworth, "Ultimate strength of continuous composite beams," Journal of Structural Division, vol. 102, no. 7, pp. 1463-1478, 1976.

[10] R. P. Johnson, R. D. Greenwood, and K. van Dalen, "Stud shear connectors in hogging moment regions of composite beams," The Structural Engineer, vol. 47, pp. 345-350, 1969.

[11] M. C. Hope-Gill and R. P. Johnson, "Tests on three three-span continuous composite beams," Proceedings of the Institution of Civil Engineers, vol. 61, no. 2, pp. 367-381, 1976.

[12] R. P. Johnson and I. M. May, "Partial-interaction design of composite beams," Structural Engineer, vol. 53, no. 8, pp. $305-311,1975$.

[13] R. P. Johnson and S Chen, "Local buckling and moment redistribution in class 2 composite beams," Structural Engineering International, vol. 1, no. 4, pp. 27-34, 1991.

[14] R. P. Johnson, Composite structures of steel and concrete, Blackwell Science, Boston, London, 2nd edition, 1994.

[15] J. A. Grant, C. Koeberl, W. U. Reimold, and P. H. Schultz, "Gradation of the Roter Kamm impact crater, Namibia," Journal of Geophysical Research, vol. 102, no. E7, pp. 16327-16338, 1997.

[16] B. G. Gautam, Y. Yiqiang, X. Liao, Z. Qiu, and S. Guo, "Experimental investigation of a slip in high-performance steel-concrete small box girder with different combinations of group studs," Materials, vol. 12, no. 17, p. 2781, 2019.

[17] R. G. Liao and J. W. Fisher, "Fatigue strength of shear connectors," Fritz Laboratory Reports, Lehigh University, Bethlehem, Pennsylvania, 1966.

[18] J. Y. R. Yen, Y. Lin, and M. T. Lai, "Composite beams subjected to static and fatigue loads," Journal of Structural Engineering, vol. 123, no. 6, pp. 765-771, 1997.

[19] N. Gattesco, E. Giuriani, and A. Gubana, "Low-cycle fatigue test on stud shear connectors," Journal of Structural Engineering, vol. 123, no. 2, pp. 145-150, 1997.

[20] S.-G. Youn and S.-P. Chang, "Behavior of composite bridge decks subjected to static and fatigue loading," Journal of ACI, vol. 95, no. 3, pp. 249-258, 1998. 
[21] R. P. Johnson, "Resistance of stud shear connectors to fatigue," Journal of Constructional Steel Research, vol. 56, no. 2, pp. 101-116, 2000.

[22] B. Wang, Q. Huang, and X. Liu, "Deterioration in strength of studs based on two-parameter fatigue failure criterion," Steel and Composite Structures, vol. 23, no. 2, pp. 239-250, 2017.

[23] B. Wang, Q. Huang, X. Liu, and W. Li, "Experimental investigation of steel-concrete composite beams with different degrees of shear connection under monotonic and fatigue loads," Advances in Structural Engineering, vol. 21, no. 2, pp. 227-240, 2018.

[24] S. Liu, "Study on the mechanical performance of continuous composite box girder bridge in the negative moment zone," Ph.D. thesis, Tongji University, Shanghai, China, 2011. 